\title{
Achievements and Trends in Biocatalytic Synthesis of Specialty Polymers from Biomass-Derived Monomers Using Lipases
}

\author{
Anamaria Todea ${ }^{1}\left(\mathbb{D}\right.$, Diana Maria Dreavă ${ }^{1} \mathbb{D}$, Ioana Cristina Benea ${ }^{1}$, Ioan Bîtcan ${ }^{1}$, Francisc Peter ${ }^{1,2, *(D)}$ and \\ Carmen G. Boeriu 1,3,*(D) \\ 1 Faculty of Industrial Chemistry and Environmental Engineering, Department of Applied Chemistry and \\ Engineering of Organic and Natural Compounds, University Politehnica Timisoara, 300001 Timisoara, \\ Romania; anamaria.todea@upt.ro (A.T.); diana.aparaschivei@upt.ro (D.M.D.); \\ ioana.benea@student.upt.ro (I.C.B.); ioan.bitcan@upt.ro (I.B.) \\ 2 Research Institute for Renewable Energy, 300501 Timisoara, Romania \\ 3 Department of Biobased Products, Wageningen Food \& Biobased Research, 6708 WG Wageningen, \\ The Netherlands \\ * Correspondence: francisc.peter@upt.ro (F.P.); carmen.boeriu@wur.nl (C.G.B.)
}

Citation: Todea, A.; Dreavă, D.M.; Benea, I.C.; Bîtcan, I.; Peter, F.; Boeriu, C.G. Achievements and Trends in Biocatalytic Synthesis of Specialty Polymers from Biomass-Derived Monomers Using Lipases. Processes 2021, 9, 646. https://doi.org/ $10.3390 /$ pr9040646

Academic Editor: Antonio Moreno

Received: 18 March 2021

Accepted: 6 April 2021

Published: 7 April 2021

Publisher's Note: MDPI stays neutral with regard to jurisdictional claims in published maps and institutional affiliations.

Copyright: (c) 2021 by the authors. Licensee MDPI, Basel, Switzerland. This article is an open access article distributed under the terms and conditions of the Creative Commons Attribution (CC BY) license (https:// creativecommons.org/licenses/by/ $4.0 /)$.

\begin{abstract}
New technologies for the conversion of biomass into high-value chemicals, including polymers and plastics, is a must and a challenge. The development of green processes in the last decade involved a continuous increase of the interest towards the synthesis of polymers using in vitro biocatalysis. Among the remarkable diversity of new bio-based polymeric products meeting the criteria of sustainability, biocompatibility, and eco-friendliness, a wide range of polyesters with shorter chain length were obtained and characterized, targeting biomedical and cosmetic applications. In this review, selected examples of such specialty polymers are presented, highlighting the recent developments concerning the use of lipases, mostly in immobilized form, for the green synthesis of $\varepsilon$-caprolactone co-polymers, polyesters with itaconate or furan units, estolides, and polyesteramides. The significant process parameters influencing the average molecular weights and other characteristics are discussed, revealing the advantages and limitations of biocatalytic processes for the synthesis of these bio-based polymers.
\end{abstract}

Keywords: bio-based polymers; polyesters; polyesteramides; $\varepsilon$-caprolactone; hydroxy acids; estolides; furan-based monomers; lipase; green chemistry

\section{Introduction}

Polymers of natural and petrochemical origin form the basis of materials used overall in daily life, as constitutive parts of food, clothes, houses, drugs, medical aids and devices, packaging, automotive, infrastructure, telecommunication, and many others. Polymers are ubiquitous in nature. Thousands of polymers are found in plants, animals, and microorganisms, where they play major roles as structural materials (e.g., cellulose and lignin in trees and plants, chitin in the exoskeleton of crabs, shrimps, insects and the cell walls of fungi, collagen and hyaluronan in the extracellular space and connective tissues in human and animal bodies), or defense materials (e.g., latex/rubber in trees and flowering plants, hyaluronan capsules in pathogenic microorganisms), among other functions [1-3]. From ancient times, people relied on natural polymers to secure their needs as silk, wool, and cellulose fibers were used to produce cloths, carpets, blankets, and ropes [4]. The development of the petrochemical industry brought for several decades the synthetic polymers in front, but its dominant position started to change when slow biodegradability, depletion of oil resources, and development of possible bio-based routes came into focus [5].

Presently, for obvious reasons (public concern about the environment and reducing dependence on limited fossil fuel resources), bio-based plastics are increasingly being accepted. Several have been commercialized in recent years, e.g., polylactic acid, polyhydroxyalkanoates, and more recently polybutylene succinate [6]. The production capacity of 
bio-based polymers was expected to triple from 5.1 million tons in 2013 to 17 million tons by 2020 [7] and has a predicted annual growth rate of $18.6 \%$ in the 2016-2021 period [8]. The aim is harnessing the total technical substitution potential of bio-based polymers replacing $90 \%$ of total petroleum-based polymers (and fibers) [9]. In this regard, the renewable production of the suitable monomers from biomass offers a promising opportunity to improve the overall economics and sustainability of an integrated biorefinery. Each year, about 170 billion tons of biomass are produced by nature; of this only 3.5\% are currently used [10]. To avoid the interference with the food chain, recent progress is focused on the microbial conversion of biomass into bio-monomers, using engineered microorganisms [11].

Research in the past decade addressed the development and/or improvement of (bio)processes to produce both bio-based polymers and bio-based monomers, of which lactic acid, succinic acid and 1,3-propanediol are the most known success stories [12]. However, the range of monomers derived from renewable resources expands far beyond these areas and grows continuously. Even though many renewable feedstocks, as vegetal oils, lignin, terpenes, amino acids, or even carbon dioxide were used as starting materials for innovative bio-based polymers, carbohydrates represent the most important source [13]. A recent review [8] properly highlighted the main (chemo)-enzymatic approaches to highvalue and structurally diverse bio-based monomers.

Obviously, the replacement of the petrochemical commodity polymers, manufactured at large scale, by substitutes obtained from renewable sources represents the main target of the future [14]. This development is not limited to commodity plastics, since an increasing number of specialty polymers were also synthesized from renewable monomer sources using chemical, chemoenzymatic, or biocatalytic routes. The consumer demand for new medical and cosmetic products will be the principal driving force of the development of this sector. The pharmaceutical sector is already one of the main beneficiaries of the high chemoselectivity, regioselectivity, and stereoselectivity of the biocatalytic reactions [15]. For example, polyesters obtained from bio-based dicarboxylic acids and diols are among the most promising green plastics for various biomedical applications, including controlled drug delivery $[16,17]$, tissue engineering, temporary implants, or wound healing [18]. Beside natural polymers, which are widely used in cosmetic formulations, the latest developments in this sector include composites based on manufactured biopolymers as nanocellulose [19], or cosmetic packaging plastics [20].

The use of biocatalysts in industrial processes is gaining wider acceptance for the purposes of eco-friendliness and cost-effectiveness [21]. Biocatalytic processes meet the needs of sustainability, by development of safer and more environmentally friendly chemistry, which equally integrates the priorities of economic competitiveness and societal concerns, also allowing the design of a new generation of polymers [22,23]. For this reason, the use of lipases as catalysts for polymerization reactions came gradually into focus in the last two decades, revealed by the increasing number of publications in this topic and being the subject of several excellent reviews by Kobayashi and his coworkers [24-30], as well as by other authors [31-34]. Biocatalytic strategies using lipases have become important bio-based alternatives to conventional polymerization methods, since several drawbacks related to the presence of metal catalyst traces, toxicity and higher temperatures could be avoided [16]. Moreover, functionalization of polymers such as polylactic acid [35] or polycaprolactone [36,37] can be accomplished using lipases, allowing improved drug delivery properties in systems needing higher hydrophilicity.

This review presents some of the latest trends and developments concerning the enzymatic synthesis of selected specialty polymers from biomass-derived monomers, such as $\varepsilon$-caprolactone, itaconic acid, hydroxy fatty acids, furan-containing monomers, amino acid derivatives (Figure 1). The biocatalytic conversion of these monomers into polyesters and polyester amides, using lipases as biocatalysts, are discussed. The integration of the bio-based monomer production with the biocatalytic polymerization step will afford a fully green, biocatalytic route to bio-based polymers. 


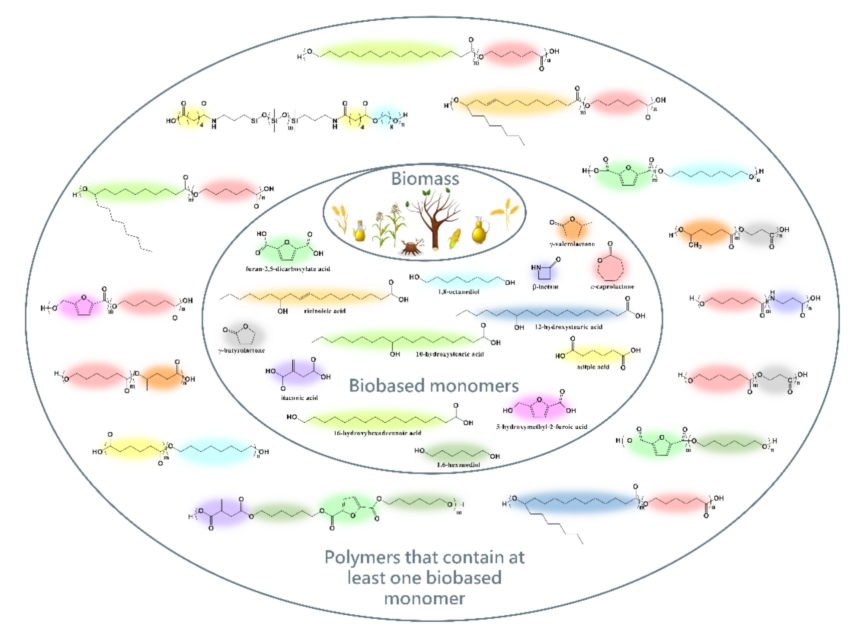

Figure 1. Examples of green polymers available through biocatalytic synthetic routes from bio-based monomers.

\section{Synthesis Opportunities and Importance of Polyesters and Polyesteramides Obtained from Biomass-Based Monomers}

Polyesters are a class of polymers bearing the ester functional group as the linkage between the individual monomers. Considering the availability of several bio-based monomers for polyester synthesis, it can be stated that this class of polymers obtained from renewable resources is among the most promising ones [38]. The approach for the synthesis of polyesters entails two different pathways: (i) ring-opening polymerization of cyclic monomers (lactones, cyclic diesters, and cyclic ketene acetals), and (ii) step-growth polycondensation of either diacids or diesters with diols or polyalcohols, or polycondensation of hydroxyacids, hydroxyesters (Figure 2) [34,39].

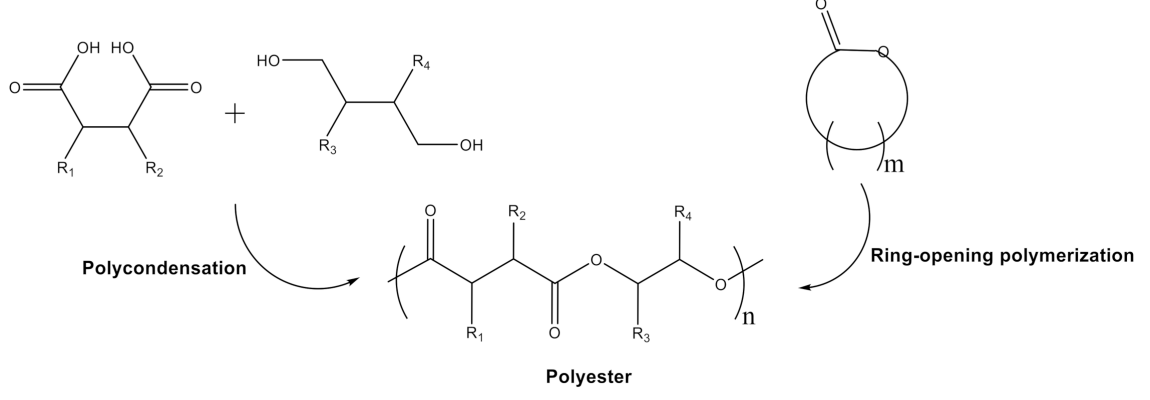

Figure 2. Pathways for polyester synthesis.

Ring-opening polymerization of cyclic esters is currently a very progressive and dynamic methodology for polyester synthesis. This strategy is integrated into a constant expansion assimilating novel bio-based monomers as improved alternatives for the synthesis of greener polyesters [40]. The polycondensation (step-growth) methodology is advantaged by the wide range of available monomers and reaction schemes. In recent years it has been intensively investigated, as it can be applied for a variety of simple diacids with diols (AA+BB-type monomers) along with using hydroxy acids (AB-type monomers) or transesterification reactions of simple or activated diesters with diols, these reactions resulting in a depletion of stoichiometric equivalents of water [41-43].

Some of the most researched biodegradable polyesters are: polyglycolic acid (PGA), polylactic acid, poly(lactide-co-glycolide), poly( $\varepsilon$-caprolactone), poly( $\omega$-pentadecalactone), poly(hydroxyalkanoates), poly(dioxanone), and poly(ethylene succinate) [44-47]. Numerous applications have been found for these biodegradable polymers, as release systems, in tissue engineering, as systems that mimic extracellular matrices, as well as in obtaining memory foams [48-52]. 
In terms of the catalysts used for the polyester formation, the in vitro employment of enzymes proceeds even further, compared to the chemical means of catalysis, by enabling the synthesis of functionalized, structured, and biodegradable polyesters upon highly selective, energy saving, and clean synthetic processes. The industry of polymers can benefit from the current biotechnological advances that allow the production of high-quality polyesters possessing novel functional and structural properties. As the enzymes involved in the synthesis of polyesters are also efficient in hydrolyzing the ester bonds, the polyesters obtained by means of biocatalysis are endowed with biodegradable properties $[33,53]$. Consequently, it can be stated that the use of biocatalysts for polyester synthesis may imply significant prospects for establishing a sustainable polymer recycling system [54].

Polymers used in medicine must meet several indispensable conditions, such as: biocompatibility, biodegradability, non-toxicity and non-immunogenicity [55]. The main goal of drug delivery systems is to maximize the therapeutic effect and minimize their side effects [56,57]. Specialty polymers synthesized using a biocatalytic pathway can respond to these requirements through the structural flexibility of the polymer chain and by functionalization with appropriate side groups.

The most relevant enzymes involved in cell-free polymerizations are lipases (EC 3.1.1.3). In nature, lipases naturally catalyze the hydrolysis of fatty acid glycerol esters. The ester bond formation can be achieved by shifting the equilibrium of the reactions in in a nonaqueous medium, together with removing inhibitory by-products [58]. Lipase-catalyzed polycondensation and ring-opening polymerization allegedly share related reaction intermediates ("acyl-enzyme intermediates"). Therefore, the potential of combining the two methods of polymerization through enzyme catalysis in the interest of producing ester co-polymers should be considered [59].

A class of bio-based monomers suitable for the synthesis of polyesters is represented by organic acids produced from monosaccharides through the biological or chemical conversion of biomass. Examples of monomers obtained from renewable resources include carboxylic acids synthetized from carbohydrates, such as adipic acid, succinic acid, lactic acid, fumaric acid, levulinic acid, citric acid, and itaconic acid [33,38,60]. In most cases, the carboxylic acids are obtained by fermentation of carbohydrates, particularly glucose. The biomass sources which can be transformed into glucose include starch, cellulose, sucrose, and lactose. Therefore, glucose is converted into polyester building blocks. The conversion can be achieved by enzymatic hydrolysis or by the chemical transformation of woody biomass, avoiding the use of raw materials from food crops [61].

Furan derivatives, such as hydroxymethylfurfural (HMF) and furfural (FAL), obtained from biomass-derived carbohydrates, can be sustainable substitutes for petroleum-based monomers [62,63] to produce alcohols and organic acids suitable for polyester synthesis. As important derivatives of furan, furoic acid (FA) and 5-hydroxymethyl-2-furancarboxylic acid (5OH2FA) are oxidative products of FAL and HMF, respectively.

Another class of monomers obtained from biomass sources are short-chain diols, such as 1,3-propanediol, 1,4-butanediol, isobutanol, sorbitol, ethylene glycol, as well as isosorbide, isomannide, and isoidide, the products of sorbitol and mannitol dehydration. The previously mentioned building blocks are suitable for polyester synthesis, being produced microbially over natural and engineered pathways [33,38,64,65].

The monomers possessing adequate characteristics for ring-opening polymerization include a series of small to large-sized lactones, lactides, and macrolides. Lactones can polymerize over a ring-opening pathway through catalysis by lipases, and their degree of polymerization is dependent on the ring size in addition to the enzyme provenience source $[41,54]$. In recent years, multifarious lactones, unsubstituted or substituted, of various ring size have been polymerized or co-polymerized by lipases of different origin [27]. Examples of the aforementioned lactones include $\beta$-propiolactone, $\alpha$-methyl- $\beta$-propiolactone, $\alpha$ dodecenyl- $\beta$-propiolactone, $\beta$-butyrolactone, $\gamma$-butyrolactone, benzyl $\beta$-malolactonate, propyl- $\beta$-malolactonate, $\gamma$-butyrolactone, $\delta$-valerolactone, $\gamma$-valerolactone, $\alpha$-methyl- $\delta$ valerolactone, $\varepsilon$-caprolactone, $\alpha$-methyl- $\varepsilon$-caprolactone, $\gamma$-methyl- $\varepsilon$-caprolactone, and $\omega$ - 
pentadecalactone $[41-43,54,60,66]$. Lactide is one of the most promising monomer sources for the synthesis of poly(lactide) (PLA) in the ring-opening polymerization reaction [67]. Macrolides available as monomers for polymerization reactions are larger ring-size lactones, including 11-undecanolide (12-membered, UDL), 12-dodecanolide (13-membered, DDL), 15-pentadeconolide (16-membered PDL), and 16-hexadeconlide (17-membered, HDL) [27]. Certain lactones such as $\gamma$-butyrolactone, $\gamma$-valerolactone, $\delta$-valerolactone, and $\varepsilon$-caprolactone can be obtained from biomass ( $\gamma$-butyrolactone from succinic acid, $\gamma$-valerolactone by hydrogenation of levulinic acid, $\delta$-valerolactone from furfural, and $\varepsilon$ caprolactone from hydroxymethyl furfural after four steps), therefore the growing research on the synthesis of lactones derived from renewable resources have demonstrated that the valorization of biomass feedstocks is an essential component for the growth of the biorefining industry [68]. $\varepsilon$-Caprolactone, lactide and glycolide are lactone-type monomers, and have been intensively investigated for medical applications [69]. Their homopolymers, as well as their co-polymers with other monomers, have found applicability as sutures, plates, and fastening systems in fracture fixation devices, as support matrices for drugs or cells, and in other clinical applications [70-72].

Among the biodegradable synthetic polymers, polyesteramides gained increasingly importance in recent years, due to the presence of both ester and amide linkages in their structure. As a result, they congregate the good degradability of the polyesters with the robust thermo-mechanical properties of polyamides, leading to particularly interesting possible applications in the biomedical domain. Polyesteramides containing $\alpha$-amino acid units in their molecule are considered the most significant in this field since the presence of these moieties contributes to better cell-polymer interactions, enhances the overall biodegradability, and allows the possible introduction of pendant reactive groups for further functionalization of the polymers [73].

Chemical synthesis represents the classical way to obtain polyesteramides (Figure 3), using two main procedures:

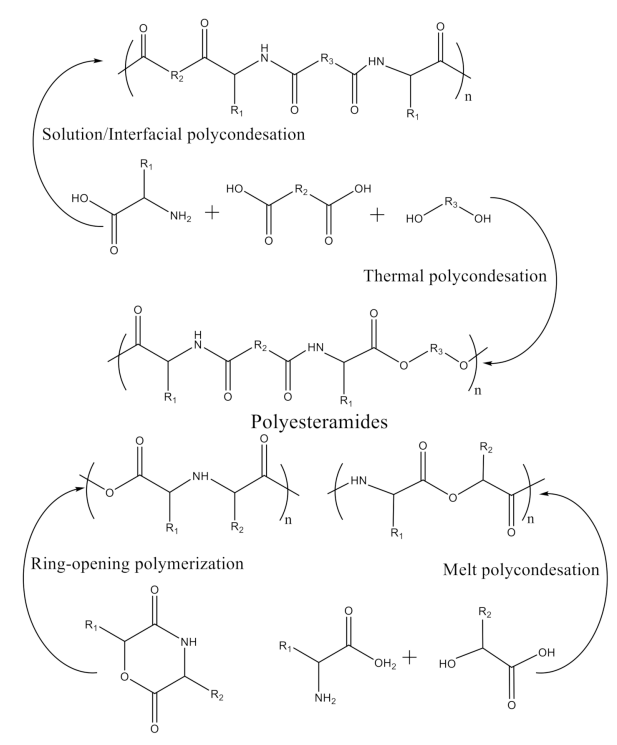

Figure 3. Pathways for polyesteramide synthesis.

(1) Polycondensation of $\alpha$-amino acids, fatty dicarboxylic acids, and diols. In this case, a diamide-diester is first synthesized by condensation of a diacyl chloride with the methyl ester of an $\alpha$-amino acid, followed by polycondensation with a diol. The reactions can be accomplished by different pathways: (i) thermal polycondensation [74]; (ii) solution polycondensation [75]; (iii) interfacial polycondensation [76].

(2) Polymerization of $\alpha$-amino acids with $\alpha$-hydroxy acids, using two main techniques: (i) ring-opening-polymerization (ROP) of cyclic depsipeptides (peptides in which one or more of amide groups are replaced by ester), particularly derivatives of morpholine- 
2,5-dione [77]; (ii) direct melt polycondensation of $\alpha$-amino acids with $\alpha$-hydroxy acids in the presence of metal catalysts [78].

Commonly, polyesteramides are synthesized from monomers bearing carboxylic acid, amine, ester, hydroxyl, and acyl halide groups. These include compounds such as $\alpha$-amino acids, $\alpha$-hydroxy acids, carboxylic diacids, fatty diacids, diols, carbohydrates, $\alpha, \omega$-aminoalcohols, and cyclic depsipeptides [73,79]. The polycondensation between a carboxylic diacid and an amino alcohol can be regarded as the most accessible pathway to produce polyesteramides on large scale. The product of polycondensation will include a repeat unit bearing both an ester and an amide functionality. Notwithstanding the simplicity of this synthesis route, it is featured with a paucity of control of the amino alcohol insertion into the polyesteramide. This will restrict the control of the polymer microstructure leading to the thermo-mechanical properties being directly influenced [79].

Since many polyesters and polyamides were successfully synthesized by enzymatic catalysis [80], the possibilities to obtain polyesteramides in the same way look obvious. Indeed, the versatility of lipases was also confirmed for the green synthesis these copolymers, as it will be shown.

Monomer examples in terms of carboxylic diacids suitable for the synthesis of polyesteramides include succinic acid, glutaric acid, adipic acid, suberic acid, sebacic acid, tetradecanedioic acid, and octadec-9-enedioic acid. It is possible to obtain succinic acid using starch from agricultural resources (wheat, corn) or lignocellulosic resources (cellulose/hemicellulose extracted from wood, plants, agricultural, and non-agricultural residues). These renewable resources can be converted into glucose after a hydrolysis treatment, this process allowing the production of succinic acid over an enzymatic fermentation process. Octadec-9-enedioic acid is obtained in the fermentation process of oleic acid, therefore it is a natural unsaturated fatty diacid [79].

Ethanolamine is a typical example of an amino alcohol extensively used in the chemical industry (production of corrosion inhibitors, polishes, chemical intermediates, emulsification agents, detergents). It is possible to obtain bio-based ethanolamine through conversion of glucose in L-serine, continued with a subsequent decarboxylation using Pseudomonas putida S12 [79].

Polyesteramides based on $\alpha$-amino acids associate the appealing properties of the conventional polyester amides with enzymatic degradability, enhancement of cell-materials interactions, and insertion of functional groups for the attachment of drugs or peptides derived from the presence of the $\alpha$-amino acid [73]. A series of amino acids used in the production of polyesteramides comprise glycine, allylglycine, lysine, alanine, arginine, glutamic acid, serine, alanine, isoleucine, phenylalanine, tyrosine $[73,81-83]$. The most abundant amino acid is glutamic acid, which can conceivably be obtained in high yields from manifold natural sources. It is presented as the main byproduct in many bio-based compound production streams, while in sugar beet vinasse glutamic acid was reported to correspond to a mass fraction of $63 \%$ of the total amino acid mass content [84]. A convenient biomass resource for the synthesis of several amino acids, such as glycine, is cellulose. Cellulose can be converted to ethanolamine, which under oxidation is converted into glycine, the simplest amino acid. Lignin is another adequate biomass resource that can ensure the intermediates in the synthesis of aromatic amino acids. A possible route that could ensure the avail of lignin is configurated in the synthesis of tyrosine via pcoumaric acid as a key intermediate. Another biomass resource that retains a noteworthy position as a starting point for the synthesis of amino acids is chitin, the prevalent nitrogencontaining biopolymer on earth [85]. As these monomers are concerned, the microbial conversion processes can enable a broad range of amino acids, which are attractive biobased chemicals for sustainable synthesis of polyesteramides, since they are currently produced in considerable amounts and at low cost $[85,86]$. Therefore, bio-based amino acid production provides considerable opportunities to develop new biocatalytic processes from renewable sources, such as biomass. In recent decades, such biocatalytic processes were developed in the frame of the biorefinery concept, providing an adequate route to transform 
multiple types of biomass or biomass components such as cellulose, hemicellulose, lignin, lipids, and chitin into valuable and beneficial chemicals [85].

A valuable monomer that can serve as a suitable building block for the synthesis of polyesteramides is also $\varepsilon$-caprolactam, the lactam of 6 -aminohexanoic acid, oftentimes co-polymerized alongside its lactone equivalent $\varepsilon$-caprolactone. The poly $(\varepsilon$-caprolactoneco- $\varepsilon$-caprolactam) co-polymers represent a novel class of bio-based polyesteramides. The main advantages of this synthesis approach are depicted in the possibility of combining the biodegradation properties of polycaprolactone, associated with the ester linkages along the chain, with the improved thermal and mechanical characteristics of polycaprolactam, associated with its capacity of developing hydrogen bonds and its polarity [81,87]. A series of biomass feedstocks can be converted into $\varepsilon$-caprolactam. In recent years, the synthesis of $\varepsilon$-caprolactam from renewable resources was expanded. Therefore, a possible intermediate in the production of $\varepsilon$-caprolactam is L-lysine, obtained from bio-sourced sugar or biobased butadiene, yielded by dehydration of bio-based 2,3-butanediol. Subsequently, sugar fermentation can render a greener pathway for the synthesis of $\varepsilon$-caprolactam $[32,88]$.

\section{Trends in the Lipase-Catalyzed Synthesis of Polyesters and Co-Polyesters of $\varepsilon$-Caprolactone}

The enzymatic synthesis of $\varepsilon$-caprolactone homopolymer and co-polymers has been intensively studied, due to the numerous application possibilities of these materials. Various lipases were tested, in most cases in immobilized form, as well as several comonomers. A selection of significant results obtained by enzymatic catalysis is presented in Tables 1 and 2, also specifying the immobilization support, if it was the case. Although native lipases led to the same range of average molecular weights, as shown in Table 2, in most cases the lipase was used in immobilized form. The large number of studies performed with lipase B from Candida antarctica immobilized on acrylic resin (Novozyme 435) confirms the status of this biocatalyst as the most frequently used in enzymatic reactions up to date. Due to its easiness and reproducibility, the enzymatic synthesis of poly(caprolactone) (PCL) was even used in recent years as a model reaction for evaluation of the catalytic efficiency of lipases in polyesterification reactions, or for evaluation of some solvents effect (e.g., ionic liquids). Although there is a diversity of characterization methods of the resulted products, including structural characterization by different techniques, thermal analysis, etc., for consistency reason the average molecular weights were selected as common characteristic and these values were included in Tables 1 and 2. Obviously, the value of this parameter is strongly dependent on the measurement method (SEC-GPC, MALDI-TOF MS or NMR) [89] but nevertheless it could be considered an expression of the biocatalyst performance or effects of the reaction conditions. The results reported in recent years indicate that average molecular weights of the products are reaction media dependent. Even though the monomer is liquid, the product is usually solid at temperatures lower than $60^{\circ} \mathrm{C}$ and for chain elongation the selection of a suitable solvent is crucial. The most used solvent was toluene, yielding polymers with average molecular weights up to 10,000 Da, excepting the study of Poojari et al. [90], where Mw values determined by GPC were about 50,000 Da. When ionic liquids were used as reaction media, an increase of the average molecular weights was observed. 
Table 1. Synthesis of poly-( $\varepsilon$-caprolactone) catalyzed by lipase.

\begin{tabular}{|c|c|c|c|c|}
\hline Source of Lipase & Immobilization Support & Reaction Conditions & Mw/Mn [Da] & Reference \\
\hline \multirow[t]{3}{*}{ C. antarctica B } & Acrylic resin Novozyme 435 & $\begin{array}{l}\text { toluene, } 70^{\circ} \mathrm{C}, 4 \mathrm{~h}, 10 \\
\text { reaction cycles }\end{array}$ & Mn: 50,000 & {$[90]$} \\
\hline & $\begin{array}{l}\text { Montmorillonite and } \\
\text { sepiolite clay }\end{array}$ & $\begin{array}{c}\text { toluene, } 70^{\circ} \mathrm{C}, 5-6 \mathrm{~h}, \text { dry } \mathrm{N}_{2} \\
\text { atm }\end{array}$ & Mn: $3300-8000$ & [91] \\
\hline & Acrylic resin Novozyme 435 & $\begin{array}{c}\mathrm{Tf}_{2} \mathrm{~N} \text {-based ionic liquids, } \\
70^{\circ} \mathrm{C}, 48 \mathrm{~h}\end{array}$ & Mn: $12,300-18,000$ & [92] \\
\hline Y. lipolytica & Lewatit Acurel & bulk, $150^{\circ} \mathrm{C}, 6 \mathrm{~h}$ & Mn: 600-1300 & [93] \\
\hline Porcine pancreas & porous silica particles & BMIMPF $_{6}, 150^{\circ} \mathrm{C}, 24 \mathrm{~h}$ & Mn: $13,500-17,000$ & [94] \\
\hline Archaeoglobus fulgidus & $\begin{array}{c}\text { Macroporous } \\
\text { hydrophobic resin }\end{array}$ & $45-80^{\circ} \mathrm{C}, 72 \mathrm{~h}$ & Mn: 850-1400 & [95] \\
\hline Y. lipolytica & & $\begin{array}{c}{\left[\mathrm{BF}_{4}\right] \text {-based ionic liquids/ }} \\
{[\mathrm{BuPy}]\left[\mathrm{CF}_{3} \mathrm{COO}\right]} \\
{[\mathrm{EMIM}]\left[\mathrm{NO}_{3}\right]} \\
60-150^{\circ} \mathrm{C}, 24 \mathrm{~h} \text {, dry } \mathrm{N}_{2} \mathrm{~atm}\end{array}$ & Mn: $1000-8000$ & [96] \\
\hline
\end{tabular}


Table 2. Synthesis of $\varepsilon$-caprolactone co-polyesters catalyzed by native and immobilized lipases.

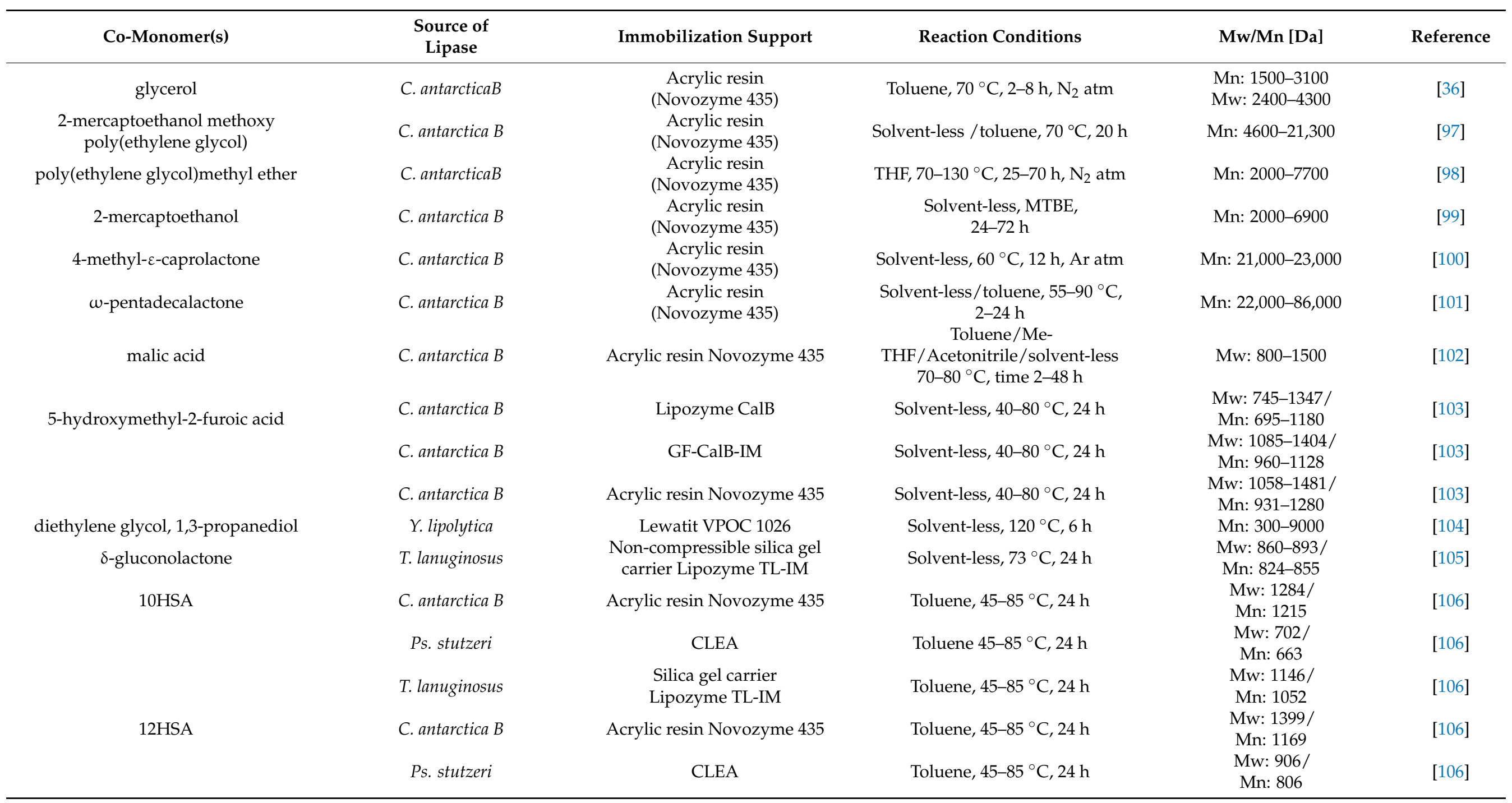


Table 2. Cont.

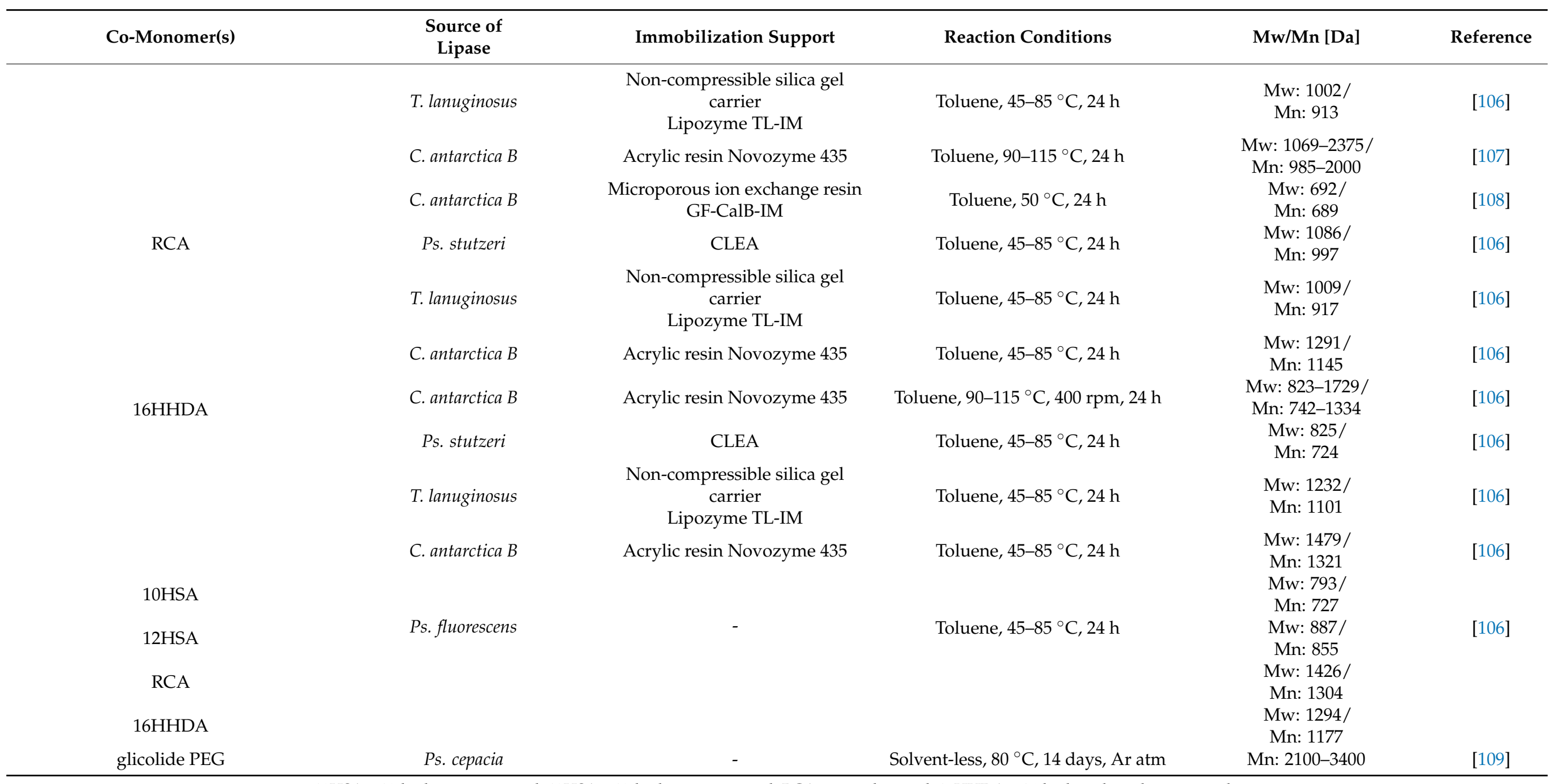


The biocompatibility, low toxicity and biodegradability properties ranks PCL as a promising material for several applications. However, the high hydrophobicity and unsatisfactory mechanical properties limit its applications. For this reason, in most cases the investigations were focused on improvement of PCL properties by different methods: chemical synthesis, grafting polymerization, as well as functionalization by enzymatic co-polymerization for insertion of various pendant groups. A selection of the most relevant results obtained by the enzymatic route in the last 15 years is presented in Table 2 . These data show that a variety of co-monomers were already investigated in co-polymerization reactions with $\varepsilon$-caprolactone, demonstrating the obvious perspectives to extend the application field of poly ( $\varepsilon$-caprolactone, already a polymer with resurgent interest [110], by synthesis of a wide range of new specialty polymers with specific functionalities and properties. In terms of molecular weights, the values were rather low, excepting the cases when other lactones were used. However, considering the mild conditions, e.g., temperatures about $80^{\circ} \mathrm{C}$, the results are promising for several applications. Recently, the enzymatically synthesized oligoesters containing $\varepsilon$-caprolactone and 12-hydroxystearic acid were used for preparation of sorafenib-loaded polymeric nanocomposites. The resulting nanoparticles showed promising drug release profile and cytotoxic effect in vitro in HepG2 hepatocellular cells [37].

\section{Developments in the Enzymatic Synthesis of Itaconic Acid Based Polyesters}

Although itaconic acid (2-methylenesuccinic acid) is a metabolite of several microorganisms, it is produced at industrial scale solely by fermentation with Aspergillus terreus, yielding about $80 \mathrm{~g} \mathrm{~L}^{-1}$ [111]. Recently, various microorganisms (Table 3) have been genetically modified to produce itaconic acid in the most efficient way possible; however, the productivity of $A$. terreus was not surpassed [112].

Table 3. Microorganisms reported as efficient producers of itaconic acid.

\begin{tabular}{ccc}
\hline Microorganism & Concentration $\left[\mathbf{g ~ L}^{-\mathbf{1}}\right]$ & Reference \\
\hline Aspergillus terreus (initial step) & $24-27$ & {$[113]$} \\
Aspergillus terreus (optimized & $\sim 86$ & {$[114]$} \\
steps) & 53 & {$[115]$} \\
Ustilago maydis & 35 & {$[116]$} \\
Candida sp. & 30 & {$[117]$} \\
Pseudozyma antarctica & non-specified & {$[118]$} \\
Macrophage & &
\end{tabular}

Itaconic acid is used in polymerization reactions due to its photoactive and biocompatible properties. The synthetic possibilities which can involve itaconic acid and its derivatives in polymerization reactions are shown in Figure 4. Such polyesters have found applicability in the medical field, tissue engineering, to obtain memory foams, resins, as well as coating varnishes [119-125].

Based on the available data, the enzymatic polycondensation for poly(itaconate)s is the only method that allows the synthesis of products with unreacted vinyl groups. As Guarneri et al. highlighted, the main goal in the case of itaconic-based polyesters is not the synthesis of long chain polymers, but to develop new bio-based functional materials by preservation of the itaconic moiety under controlled reaction conditions [126]. A selection of the itaconic-based polyesters synthesized with lipases as biocatalysts is presented in Table 4, indicating that up to date a diester of itaconic acid was preferred as raw material, combined with at least a diol and in some cases with a third substrate. In all presented examples the commercially available immobilized lipase from Candida antarctica B (Novozyme 435) was used, excepting the researchers from the University of Trieste (Italy) who employed their own biocatalyst, Candida antarctica B lipase covalently immobilized on different supports [126]. 


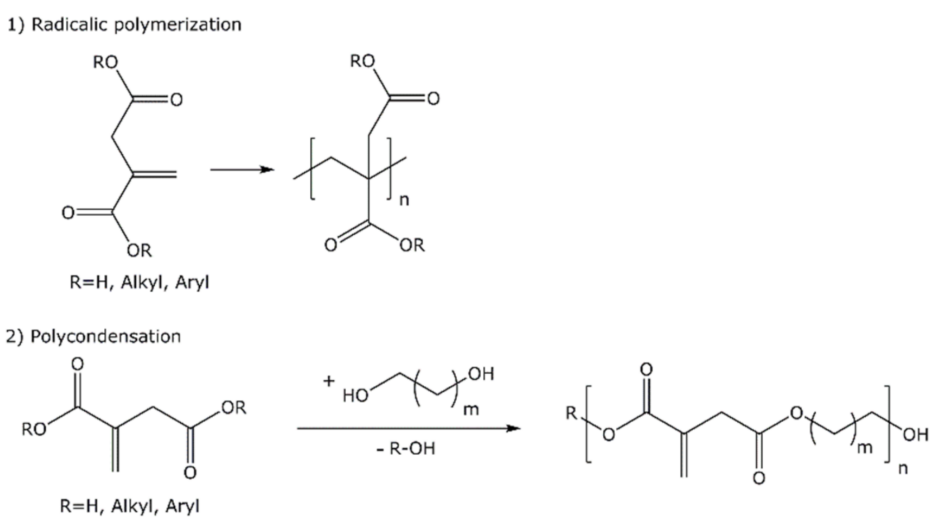

Figure 4. Polymerization possibilities of itaconic acid derivatives.

Table 4. Lipase-catalyzed synthesis of itaconic acid co-polyesters.

\begin{tabular}{|c|c|c|c|c|}
\hline Itaconic Monomer & Co-Monomer(s) & Reaction Conditions & $\mathrm{Mw} / \mathrm{Mn}[\mathrm{Da}]$ & Reference \\
\hline DMI & $\begin{array}{l}\text { 1,4-cyclohexanedimethanol } \\
\text { (PEG; } 400 \mathrm{Da}) \\
\text { 3-methyl-1,5-pentanediol }\end{array}$ & $\begin{array}{l}90^{\circ} \mathrm{C} \text {, inert atm, } \\
\text { Low pressure, } 48 \mathrm{~h}\end{array}$ & Mn: 2000-11,900 & [123] \\
\hline DMI & $\begin{array}{c}\text { 1,4-BDO/1,4- } \\
\text { Cyclohexanedimethanol }\end{array}$ & Solvent-less, $50^{\circ} \mathrm{C}, 72 \mathrm{~h}, 70 \mathrm{mbar}$ & Mw: 720-2859 & [126] \\
\hline DMI & 1,4-BDO & Solvent-less, $50^{\circ} \mathrm{C}, 70 \mathrm{mbar}$, thin film & n.d. & [127] \\
\hline DMI & $\begin{array}{c}\text { 1,4-BDO } \\
\text { CHDM }\end{array}$ & Solvent-less, $50^{\circ} \mathrm{C}, 70 \mathrm{mbar}$, thin film & n.d. & [128] \\
\hline IA/DMI/DIE/DBI & $\begin{array}{l}\text { Diethyl succinate }+1,4 \text {-butandiol } \\
\text { 1,4-butanediol and diethylsucci- }\end{array}$ & $\begin{array}{c}\text { Diphenyl ether, } 80{ }^{\circ} \mathrm{C}, 2-94 \mathrm{~h} \\
\text { Diphenyl ether }\end{array}$ & Mn: 730-1403 & [129] \\
\hline DMI & $\begin{array}{l}\text { nate/diethylglutarate/ } \\
\text { diethyladipate/diethylsebacate }\end{array}$ & $\begin{array}{c}\text { I. } 80{ }^{\circ} \mathrm{C}, 2 \mathrm{~h}, \mathrm{~N}_{2} \text { atm } \\
\text { II. } 80^{\circ} \mathrm{C}, 2 \mathrm{mmHg}, 94 \mathrm{~h}, \mathrm{~N}_{2} \text { atm }\end{array}$ & Mw: up to 94,000 & [130] \\
\hline DMI & 1,6-HDO+DMFDC & Toluene, $80^{\circ} \mathrm{C}, 4-72 \mathrm{~h}$ & Mn: 836-1205 & [131] \\
\hline DMI & $\begin{array}{l}\text { dimethyl succinate } \\
\text { +1,4-butanediol }\end{array}$ & $\begin{array}{c}60{ }^{\circ} \mathrm{C} \\
5 \mathrm{~h} \mathrm{~N}_{2} \text {-atm } \\
6 \mathrm{~h} 200 \mathrm{mmbar}\end{array}$ & $\begin{array}{l}\text { Mn: } 840 \\
\text { Mw: } 1500\end{array}$ & [132] \\
\hline DIE & $\begin{array}{c}\text { Isosorbide/Isomannide/Isoidide } \\
\text { 1,4-BDO } \\
\text { 1,6-HDO }\end{array}$ & $\begin{array}{c}\text { Cyclohexane:toluene } 6: 1, \text { molecular } \\
\text { sieves, magnetically, } 90{ }^{\circ} \mathrm{C}, \\
168 \mathrm{~h} / 48 \mathrm{~h} \\
\text { Diphenyl }\end{array}$ & Mw: 350-27,000 & [133] \\
\hline DMI & Diethyl succinate $+1,4$-butandiol & $\begin{array}{c}\text { ether/toluene } / \text { cyclohexane } / 80^{\circ} \mathrm{C} \text {, } \\
96 \mathrm{~h}\end{array}$ & Mn: 500-1400, 22,000 & [134] \\
\hline $\begin{array}{l}\mathrm{DMI} / \mathrm{DMF} / \mathrm{DMM} / \\
\mathrm{DBI} / \mathrm{DBF}\end{array}$ & $\begin{array}{l}1,4-\mathrm{BDO} \\
1,6-\mathrm{HDO} \\
1,8-\mathrm{ODO}\end{array}$ & $\begin{array}{c}\text { Solvent-less, } 85^{\circ} \mathrm{C} \\
6 \mathrm{~h}, 1000 \mathrm{mbar}+20 \mathrm{mbar}, 18 \mathrm{~h}\end{array}$ & Mn: up to 3000 & [135] \\
\hline
\end{tabular}

IA-itaconic acid, DMI-dimethyl itaconate, DIE-diethyl itaconate, DBI-dibutyl itaconate, DMF-dimethyl fumarate, DEF-diethyl fumarate, DEG—diethyl transglutaconate, DMM—dimethyl maleate, DBF-dibutyl fumarate, DMFDC—dimethyl furan-2,5-dicarboxylate, DES-diethyl succinate.

An important study of itaconic acid polyesters was conducted by Barrett et al. [123] by thermal or enzymatic polycondensation. The co-polymers were synthesized at $90{ }^{\circ} \mathrm{C}$ in the presence of Novozyme 435. The results obtained by the enzymatic route were remarkable, reaching molecular masses of $12,000 \mathrm{Da}$. The synthesized polyesters were subjected to the cross-linking process in the presence of ultraviolet radiation and a photo initiator (diethoxy acetophenone). As expected, the properties of the materials changed, the flexibility being greater with the addition of adipic acid. This study showed the potential of polyesters containing itaconic acid in the biomedical and biotechnological field, with the possibility of their application in sutures, stents, or drug-releasing particles [123].

The selectivity of the lipase for dimethyl succinate and for the unconjugated part of dimethyl itaconate has been demonstrated by Muller et al., resulting in polyesters with predominantly terminal itaconate units. From the point of view of thermal analysis, the enzymatically synthesized polyesters were semi-crystalline, while the chemically obtained polyesters were amorphous. Considering the average molecular weights there were not 
very large differences, by using the enzyme it reached $840 \mathrm{Da}$, while by using a metal catalyst $880 \mathrm{Da}$ was obtained. Moreover, during the biocatalytic process side reactions or color changes were not observed, as in the case of the metal catalyst [136]. Pellis et al. developed a method of covalent binding of lipase B from Candida antarctica, immobilizing it on a methacrylic resin functionalized with epoxy groups. The immobilized enzyme was successfully used in the polycondensation of dimethyl itaconate with 1,4-butanediol, and the enzyme retained its catalytic activity even after several reaction cycles. However, the molecular masses of the synthesized polyesters were not very high [127]. In a subsequent study, the same researchers tried to improve the molecular weights, showing the influence of the concentration and structure of the diols used [128].

The enzymatic synthesis of polyesters from diethyl succinate, dimethyl itaconate and 1,4-butanediol was investigated by Jiang et al. in several solvents, the highest molecular weights being obtained in diphenyl ether [129]. Subsequently, the same group succeeded in the enzymatic synthesis of high-molecular-weight polyesters using 1,4-butanediol, dimethyl itaconate and another diester (diethyl succinate, diethyl glutarate, diethyl adipate, and diethyl sebacate). The influence of the carbon atom chain in the diester molecule on the molecular weights of polyesters has been shown, Novozyme 435 with a higher specificity for diethyl adipate [130].

Polyester prepolymers using itaconic acid and oligo(ethylene glycol) were enzymatically synthesized and subsequently functionalized with various amines (piperidine, morpholine, imidazole and dialylamine) [137].

Yamaguchi et al. reported another approach to obtaining unsaturated polyesters. Along with itaconic anhydride, they also used succinic and glutaric anhydride in polyester syntheses, as well as several diols: 1,4-butanediol, 1,6-hexanediol, 1,8-octanediol and 1,10 -decanediol. The reaction produced polyesters in $68-92 \%$ yields, and structural investigations showed that the polyester double bonds were not affected in the enzymatic polymerization reaction [138].

Novel terpolymer structures containing two functionalities (itaconate unit and furan ring) were synthesized from furan-2,5-dicarboxylate, dimethyl itaconate, and 1,6hexanediol, with more than $80 \%$ yield and average molecular weights of about $1200 \mathrm{Da}$, in toluene at $80^{\circ} \mathrm{C}$, using two immobilized lipases from Candida antarctica B [131].

\section{Hydroxy Fatty Acids as Source for Enzymatic Synthesis of Bio-Based Estolides}

Estolides (Figure 5) are natural oligomers generally composed from fatty hydroxy acids. Estolides have high viscosity, good oxidative stability, high biodegradability, so they have considerable potential for obtaining lubricants, plasticizers, cosmetic additives, and components in paints [139].

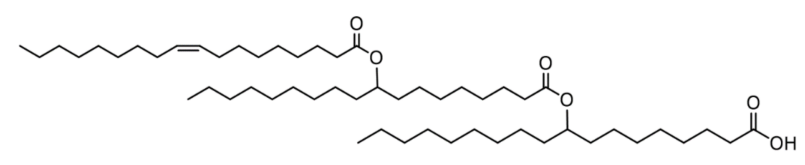

Figure 5. General structure of estolides.

Chemical synthesis of estolides can be carried out from hydroxy acids, at high temperatures and pressures [140]. A new class of complex estolides, with superior thermal properties at low temperatures, were synthesized from oleic acid and saturated fatty acids at various molar ratios, using perchloric acid as a catalyst. The separation was performed by Kugelrohr distillation, and the yields were between 45 and $65 \%$. Saturated estolides and simple esters showed different physical properties [141]. Simple oleic acid homo-estolides showed better oxidative stability than fluids based on vegetable oils or petroleum, when formulated with a low amount of oxidative stabilizer.

The second ester bond in the estolide structure is more robust compared to triglycerides, and hydrolysis is difficult. This structural aspect of estolides gives superior prop- 
erties at low temperatures, in addition to the inherent properties of a fatty acid. The biodegradability of estolides has also been demonstrated [142].

Enzymatic polymerization was scarcely used for the synthesis of estolides, but led to very promising results, opening the way of further developments.

Certain hydroxy esters, such as ethyl esters of 3-hydroxybutyric acid, 4-hydroxybutyric acid, 5-hydroxyhexanoic acid, 6-hydroxyhexanoic acid, 5-hydroxydodecanoic acid and 15-hydroxypententecanoic acid were polymerized enzymatically and the polyesters had molecular weights in the range of 3800-5400 Da [143].

Ricinoleic acid estolides were synthesized using native and immobilized lipase from Candida rugosa, at moderate temperature, in a bioreactor. The lipase was immobilized on 10 different supports by covalent binding and physical adsorption, an anion exchange resin being the most effective [144].

A lipase from Staphylococcus xylosus (SXL2), immobilized by adsorption on $\mathrm{CaCO}_{3}$, was used for the synthesis of ricinoleic acid estolides, in both organic and solvent-free systems. The highest conversions (about 65\%) were obtained in the solvent-free system at $55^{\circ} \mathrm{C}$. The structure of the estolide was demonstrated by LC-MS, FT-IR and ${ }^{13} \mathrm{C}-\mathrm{NMR}$ [145].

High-molecular-weight polyesters (polymerization degree 10) were enzymatically synthesized from 10-hydroxydecanoic and 11-hydroxyundecanoic acid, using C. rugosa lipase as catalyst. In the case of 11-hydroxyundecanoic acid, molecular masses of approximately 22,000 Da were obtained in the presence of molecular sieves. In the case of hydroxy acids, their reactivity in polycondensation reactions decreased in the following order: 16-hydroxyhexadecanoic acid $\approx 12$-hydroxydodanoic acid $\approx 10$-hydroxydecanoic acid $>6$-hydroxyhexanoic acid. It has been stated that for this type of polycondensation reaction lipases show higher reactivity in case of longer chain monomers, due to a stronger activating effect of the more hydrophobic substrates [143].

Four different estolides, with polymerization degrees up to 10, were obtained from 10hydroxystearic acid, 12-hydroxystearic acid, 16-hydroxyhexadecanoic acid and ricinoleic acid, using several native and immobilized lipases, in organic media. The substrate specificity and selectivity of these biocatalysts were evaluated. The lipase from Pseudomonas stutzeri immobilized by cross-linking as cross-linked enzymes aggregates (CLEAs) was the best biocatalyst in terms of chain elongation. The possibility of directing these reactions in order to obtain lactones or estolides with different degrees of polymerization was also demonstrated [146].

\section{Lipase-Catalyzed Synthesis of Polyesters Containing Furan Rings}

To date, several synthetic routes to polymers with furan rings have been reported, such as polycondensation reactions of 2,5-furandicarboxylic acid (FDCA), 2,5-bis-(hydroxymethyl)furan (BHMF), and 2,5-diformylfuran (DFF) [147].

The most important polyester based on 2,5-furandicarboxylic acid is poly(ethylene 2,5-furandicarboxylate) (PEF) [148]. The chemical structure, thermal stability, and aromatic nature of FDCA make it possible to replace terephthalic acid in the synthesis of polyesters, e.g., poly(ethylene terephthalate) (PET) [149-151], poly(butylene terephthalate) (PBT) [152-155], poly(propylene terephthalate) (PPT) [156,157] and poly (butylene adipateco-butylene terephthalate) (PBAT) [158,159]. The use of polyethylenefuranoate (PEF) as a substitute for polyethylene terephthalate (PET) has been also extensively studied, and the obtained results were promising: 11 times lower $\mathrm{O}_{2}$ permeability [160], 19 times better $\mathrm{CO}_{2}$ permeability and 127 times better $\mathrm{CO}_{2}$ diffusion [161], together with a 1.8 times higher $\mathrm{H}_{2} \mathrm{O}$ sorption capacity and 5 times reduction of water diffusion [162,163]. Significant differences between the two polymers were attributed to the replacement of the non-polar phenolic ring of PET with the polar furan ring in PEF.

To improve the properties of polymers containing furan units, particularly to increase their biodegradability, several other co-polymers were also synthesized. The main reported strategy involves the use of FDCA as the monomer with furan ring and of other biodegradable monomers, such as aliphatic acids or diols. 
Some of the most relevant results for enzymatic synthesis of furan-based polyesters were included in Table 5. All the studies were carried out with Novozyme 435. The reported reaction conditions indicate reaction temperatures in the range of $60-140{ }^{\circ} \mathrm{C}$, in organic media or solvent-less systems, and in some cases with a careful control of the pressure.

Table 5. The enzymatic synthesis of polyesters containing furan moieties, using Novozyme 435 as biocatalyst.

\begin{tabular}{|c|c|c|c|c|}
\hline $\begin{array}{l}\text { Monomer with } \\
\text { Furan Ring }\end{array}$ & Co-Monomer(s) & Reaction Conditions & Mw/Mn [Da] & Reference \\
\hline bis(hydroxymethyl)furan & DES/DEG/DEA/DES & $\begin{array}{c}\text { Diphenyl eter } \\
80^{\circ} \mathrm{C}, 2 \mathrm{~h} \text {, atm } \\
80^{\circ} \mathrm{C}, 4 \mathrm{~h}, 350 \mathrm{mHg} \\
80^{\circ} \mathrm{C}, 66 \mathrm{~h}, 2 \mathrm{mHg} \\
\text { I. Toluene, } 60-100^{\circ} \mathrm{C} \text { for } 72 \mathrm{~h}\end{array}$ & Mn: 2100-3000 & [164] \\
\hline DMFDCA & $1,8-\mathrm{ODA}$ & $\begin{array}{c}\text { II. diphenyl ether: (4 steps) different } \\
\text { pressures } \\
80^{\circ} \mathrm{C}, 8 \mathrm{~h} \text {, atm pressure, } \mathrm{N}_{2} \text { atm } \\
80^{\circ} \mathrm{C}, 16 \mathrm{~h}, 450 \mathrm{mmHg}, \mathrm{N}_{2} \text { atm } \\
90^{\circ} \mathrm{C}, 36 \mathrm{~h}, 100 \mathrm{mmHg}, \mathrm{N}_{2} \text { atm } \\
140^{\circ} \mathrm{C}, 12 \mathrm{~h}, 100 \mathrm{mmHg}, \mathrm{N}_{2} \text { atm } \\
\text { Diphenyl ether, }\end{array}$ & $\begin{array}{l}\text { I. Mn: } 7600-13400 \\
\text { Mw: 11,800-48,300 } \\
\text { II. Mn: 4000-11100 } \\
\text { Mw: } 10,500-54,000\end{array}$ & [165] \\
\hline DMFDCA & $\begin{array}{l}\text { 1,3-PDO/1,4-BDO/1,6- } \\
\mathrm{HDO} / 1,8-\mathrm{ODO} / 1,10- \\
\mathrm{DDO} / \mathrm{D}- \\
\text { sorbitol/glycerol/ } \\
\text { isosorbide }\end{array}$ & $\begin{array}{c}\text { A. I. } 80^{\circ} \mathrm{C}, 2 \mathrm{~h}, \mathrm{~atm},+ \text { II. } 80^{\circ} \mathrm{C}, \\
2 \mathrm{mmHg} 72 \mathrm{~h} . \\
\text { B. I. } 80^{\circ} \mathrm{C}, 2 \mathrm{~h} \text { atm, } \\
+ \text { II. } 80^{\circ} \mathrm{C}, 2 \mathrm{mmHg} 24 \mathrm{~h} \\
+ \text { III. } 95^{\circ} \mathrm{C}, 2 \mathrm{mmHg} 24 \mathrm{~h} \\
\text { +IV. } 95 / 120 / 140^{\circ} \mathrm{C}, 2 \mathrm{mmHg} 24 \mathrm{~h}\end{array}$ & $\begin{array}{l}\text { Mn: 200-23,700 } \\
\text { Mw: } 800-48,700\end{array}$ & [166] \\
\hline DMFDCA & C2-C12 diols & $\begin{array}{l}\text { Toluene:t-butanol }=70: 30 \% \text { wt., } 40^{\circ} \mathrm{C} \text {, } \\
24 \mathrm{~h}\end{array}$ & n.d. & {$[167]$} \\
\hline $\begin{array}{c}\text { cyclic butylene } \\
\text { 2,5-furandicarboxylate }\end{array}$ & $\varepsilon$-caprolactone & Solvent-less, $130-150^{\circ} \mathrm{C}, 24 \mathrm{~h}, \mathrm{~N}_{2}$ atm & Mw: 22,000-50,000 & [168] \\
\hline DMFDCA & DODA/DETA/EDDA & $\begin{array}{c}\text { Solvent-less/Toluene, } 90^{\circ} \mathrm{C} 72 \mathrm{~h} \text {. } \\
\text { Diphenyl ether, }\end{array}$ & Mn: 6360,8030 & [169] \\
\hline DMFDCA+ BHMF & $\begin{array}{l}\text { aliphatic linear } \\
\text { diols/diacid ethyl esters }\end{array}$ & 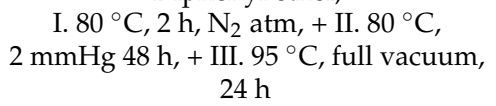 & Mw: up to 35,000 & [170] \\
\hline $\mathrm{DET} / \mathrm{DEF} / \mathrm{DEF}$ & $\mathrm{BDO} / \mathrm{HDO} / \mathrm{ODO}$ & $\begin{array}{c}\text { DPE/Bulk- } 85^{\circ} \mathrm{C}, 6 \mathrm{~h}, 1000 \mathrm{mmbar}+ \\
90 \mathrm{~h}, 20 \mathrm{mmbar}\end{array}$ & Mn: 1500-2000 & {$[171]$} \\
\hline DMFDCA & $\begin{array}{c}\text { 1,4-BDO/1,4- } \\
\text { cyclohexanedimethanol }\end{array}$ & $\begin{array}{l}\text { diphenyl ether/solvent-less } \\
80 \text { to } 140^{\circ} \mathrm{C} \text { for } 2 \mathrm{~h}+80 \text { to } 140{ }^{\circ} \mathrm{C} \text {, } \\
2 \mathrm{mmHg}, 24 \text { to } 72 \mathrm{~h} \text {. }\end{array}$ & $\begin{array}{l}\text { Mn: 695-2648 } \\
\text { Mw: 431-8173 }\end{array}$ & [172] \\
\hline
\end{tabular}

DES-diethylsuccinate, DEG—diethyl glutarate, DEA—diethyl adipate, DES—diethyl sebacate, DMFDCA—dimethyl furan-2,5dicarboxylate, 1,8-ODA-1,8-octanediamine, DODA-4,9-dioxa-1,12-dodecanediamine, EDDA-1,2-bis(3-aminopropylamino) ethane, DETA—diethylenetriamine, DET—diethyl terephthalate, DEI—diethyl isophthalate.

FDCA or its derivatives have been involved in numerous polyesterification reactions, to obtain new materials with improved properties. Monomers used in polymerization reactions with FDCA or its derivatives include: 1,3-propanediol, 1,4-butanediol, 1,6-hexanediol, 1,8-octanediol, 2,3-butanediol, 2-methyl-1, 3-propanediol, 1,4-cyclohexane-dimethanol, and isosorbide $[150,173,174]$.

Jiang et al. used Novozyme 435 for the synthesis of polyesters containing 2,5-bis (hydroxymethyl)furan and diethyl esters: diethyl succinate, diethyl glutarate, diethyl adipate, and diethyl sebacate. The reactions were carried out in diphenyl ether at $80^{\circ} \mathrm{C}$, applying vacuum to remove the resulting alcohols. Despite the different number of carbon atoms in the repeating unit, all polyesters obtained via this route had molecular weights of less than $2000 \mathrm{Da}$ [164].

Enzymatic polymerization of an FDCA derivative with different alcohols was the subject of another study. 1,3-Propanediol, 1,4-butanediol, 1,6-hexanediol, 1,8-octandiol, 1,10-decanediol, 2,3-butanediol, diethylene glycol, isosorbide, D-sorbitol and glycerol were used in polymerization reactions with dimethyl 2,5-furandicarboxylate (DMFDC). The processes were performed in diphenyl ether, at temperatures between $80-140{ }^{\circ} \mathrm{C}$, better results being obtained in the case of diols with more than three carbon atoms in the molecule [166]. 
Enzymatic syntheses of co-polyesters have been reported using two 5-hydroxymethylfurfural (HMF) derivatives and aliphatic diols, respectively a second type of co-polyesters in which the diols have been replaced by diethyl esters of some diacids. Thus, dimethyl 2,5-furandicarboxylate (DMFDC) and 2,5-bis(hydroxymethyl)furan (BHMF) were polyesterified with 1,4-butanediol, 1,6-hexanediol, 1,8-octanediol, 1,10-decanediol and 1,12-dodecanediol, respectively, using diphenyl ether as reaction medium and Novozyme 435 as catalyst. In the same manner, co-polyesters with DMFDC, BHMF, and diethyl succinate, diethyl adipate, diethyl suberate, diethyl sebacate, and diethyl dodecandioate, respectively, were synthesized. In the case of diol-coated co-polyesters, an enzyme preference was observed for diols with more methylene groups $(8,10$ and 12$)$, compared to diols with a shorter methylene chain (4 and 6). The use of 1,8-octanediol yielded a polymer with degree of polymerization of 122 , the highest among the tested diols. Using diesters instead of diols as the third co-monomer, the highest degree of polymerization was obtained for the copolyester containing diethyl adipate. The use of diesters as co-monomers led to a decrease of the polymerization degrees, compared to the co-polyesters synthesized with diols [170].

A. Cruz-Izquierdo et al. studied the enzymatic catalyzed polyesterification reactions using dimethyl 2,5-furandicarboxylate (DMFDC) and a series of diols with carbon atoms between 2 and 12, in a mixture of organic solvents. The reactions were carried out at $40{ }^{\circ} \mathrm{C}$, in a 7:3 toluene:tert-butanol mixture, for $24 \mathrm{~h}$. The co-polymer content and the degree of polymerization increased in the order: $\mathrm{C} 2<\mathrm{C} 12<\mathrm{C} 10<\mathrm{C} 3<\mathrm{C} 8<\mathrm{C} 4<\mathrm{C} 6$, where the numbers represent the carbon atoms in the diol molecule. Thus, a correlation with the length of the hydrocarbon chain of the diol could not be established [167].

Morales-Huerta et al. carried out the synthesis of poly ( $\varepsilon$-caprolactone-co-butylene 2,5furandicarboxylate) with molecular weights up to 50,000 Da, in two steps. First, the cyclic polyester poly(butylene furanoate) was obtained in the presence of Sn(II) 2-ethylhexanoate, followed by enzymatic ring-opening polymerization using lipase from Candida antarctica B [175].

One important technological limitation of the biocatalytic synthesis of these products is that the molecular weight of the co-polyesters seems to be restricted by the incorporation of aromaticity in the backbone [170].

\section{Tendencies in Enzymatic Synthesis of Polyesteramides}

Though the important developments concerning the chemical synthesis of polyesteramides in recent years, the disadvantages of using chemical catalysts, particularly the high temperatures needed and the possible toxicity due to metal traces present in the product are obviously hampering the use of these materials. In these conditions, it was predictable that enzymatic polycondensation would be considered to be a possibility not only for the synthesis of polyesters and polyamides, but also for polyesteramides, as recently reviewed by Douka et al. [42].

The synthesis of a polyesteramide, from diethyl adipate, $\alpha, \omega$-(diaminopropyl)polydimethylsiloxane, and 1,8-octanediol, using Novozyme 435 as biocatalyst, was first described more than a decade ago [176]. Using the same Novozyme 435, another interesting type of specialty polyesteramides, silicone fluorinated aliphatic polyesteramides, were synthesized by Palsule and Poojari using as starting materials $\alpha, \omega$-aminopropyl terminated poly(dimethylsiloxane), diethyl adipate, and different fluorinated alkanediols. The effect of the chain length of the fluorinated alkanediols on the molecular weight of the polymers showed that the highest values were obtained using the 3,3,4,4,5,5,6,6-octafluoro-1,8octanediol as monomer [177]. Although the possibility of synthesizing polymers including both ester and amide linkages by lipase biocatalysis was demonstrated in these works, the interest for such processes was not relevant in the next years. However, some reports published mainly in the last period focused again the interest on this topic.

Raghupathy et al. used Novozyme 435 to catalyze the polycondensation reaction between different aliphatic oligoesters and diamines by precipitation polymerization in 
three steps, at elevated temperatures, yielding poly(amide-co-ester)s with the highest $\mathrm{Mn}$ of about $17,000 \mathrm{Da}[178]$.

The polymerization of $\varepsilon$-caprolactone with $\beta$-lactam yielded the polyesteramide copolymer, together with the corresponding homopolymers, with random distribution of the monomeric units in the polymer chain [179]. The group of Prof Katja Loos reviewed the outcomes of the enzymatic synthesis of polyesteramides from the scientific literature until 2015 [80].

Direct enzymatic polymerization reaction between $\alpha$-amino acids and hydroxy acids or lactones could be a viable synthetic way to obtain polyesteramides but is hindered by some drawbacks, as results from the following example. A recent study concluded that direct polymerization of $\varepsilon$-caprolactone with sulfur-containing amino acids cysteine and methionine was not successful, probably due to the poor solubility of the amino acids in the employed reaction media and poor affinity with the lipase binding site. Consequently, a different strategy was used, with a protected amino acid derivative, N-Boc cysteine hexyl ester. Even in these conditions, the insertion of the amino acid along the polycaprolactone chains, catalyzed by Novozym 435, remained limited to chain endcapping [180].

To overcome the difficulties of the enzymatic polyesteramide synthesis, Liang et al. [181] carried out the polycondensation starting from four monomers, $\mathrm{N}$-(6-hydroxyhexanoyl) aspartate diesters with an L- or D-aspartate configuration, and methyl or benzyl ester groups at the $\alpha$-or $\beta$-carbonyl positions of aspartic acid. The L-aspartate diesters monomer was preferred to the D-aspartate diesters monomer in the enzymatic polycondensation, and the reaction, carried out with Novozyme 435, also showed regioselectivity, with preference to the $\beta$-linkage of the aspartate unit [181].

Obviously, the significant advantages of using enzymatic catalysis, encompassed into a green chemistry concept, were not fully exploited for the synthesis of polyesteramides, probably due to the drawbacks related to the limited solubility of the substrates and difficulty of finding the enzyme with appropriate selectivity and catalytic efficiency for such processes. It is easy to observe that actually the well-known Novozyme 435 has been used as catalyst in all studies, without investigating other lipases or substrate-directed immobilization techniques.

\section{Conclusions and Outlook}

The use of enzymes in polymerization reactions in vitro has already been recognized as a viable alternative for the traditional transition metal catalysts in the synthesis of polyesters [182]. However, industrial implementation of these biocatalytic polymerization processes is still waiting, as several difficulties hamper their scaling-up, particularly for the manufacturing of commodity plastics with high molecular weights. The main challenges of polyester production by cell-free enzymatic catalysis were revealed in an excellent review of Gross et al. 10 years ago [58], and the situation has not changed significantly since that time. Therefore, we consider that biocatalytic synthesis of specialty polymers, particularly of new structures which still are not manufactured by chemical catalysis and could be considered niche products, might have higher probability for successful scaling up and gain market acceptance. The synthesis of such products could benefit of the broad substrate specificity of lipases to synthesize a wide range of polymers, allowing at the same time the fine tuning of the process by appropriate selection of: (i) the enzyme source; (ii) the immobilization technique and conditions; (iii) the reaction engineering parameters, such as monomer ratio, temperature, reaction medium (organic solvent, green solvent, or solvent-less).

The bio-based polymers presented in this review already gained scientific interest in the topic of specialty polymers synthesized with lipases and were considered of importance for future development, in the author's view. Enzymatic polymerizations are yielding products with lower molecular weights, often below 10,000 Da, also depending on the assay method, as the most widely applied GPC method with polystyrene calibration can often overestimate the real values. Therefore, many of these products could be considered rather oligomers, even if a clear border between polymers and oligomers is difficult to be drawn, 
since according to the IUPAC recommendations an oligomer has a "small plurality of units" (without indicating a maximal polymerization degree) and should have "properties which do vary significantly with the removal of one or a few of the units" [183].

Nevertheless, polycaprolactone is one of the most exciting old/new polymers considering its degradation behavior, biocompatibility, and unique possibilities to build novel structures, such as block co-polymers or co-polymers. This renewal of the interest towards polycaprolactone was emphasized since the possibility to obtain bio-based $\varepsilon$-caprolactone was demonstrated, even if it is not yet implemented at industrial scale. Consequently, several interesting new materials were obtained through co-polymerization or end-functionalization catalyzed by lipases, targeting mostly biomedical applications. It must be pointed out the successful use of several hydroxy acids as co-monomers, generating a range of functionalized co-polymers, although the lower molecular weights and random distribution of the structural units could generate difficulties concerning the reproducibility of the properties. The development in this topic will probably mean tailor-made immobilized lipases with higher catalytic efficiency for chain elongation, and improved process engineering by selection of reaction media or solvent-less conditions, allowing the increase of the reaction temperature and decrease of the diffusion constraints. Another important objective of the future can be the further development of materials with aromatic rings included in the polycaprolactone chain.

Enzymatic synthesis of itaconate co-polymers and terpolymers with several diols and diacids or diesters emerged as one of the best possibilities to preserve the itaconate double bound, avoiding the undesirable side reactions which are common during the conventional polyesterification of such monomers [184]. In this way, the post-polymerization modification of these polymers, e.g., by aza-Michael additions, becomes more effective, particularly when itaconate is present as a terminal unit. In this way, biocatalysis can be efficiently combined with chemocatalysis, leading to new polymer architectures with tremendous applications, which will represent probably one of the main directions of future developments, also considering the availability of bio-based itaconic acid, one of the most important platform chemicals.

Estolides synthesized from fatty acids have excellent lubricant and cold-flow properties, with important applications as bio-lubricant base oils for automotive and industrial applications, as well as cosmetic ingredients [185]. Although the possibility of a fully biobased synthetic route to estolides, starting from vegetal oils and involving only biocatalytic steps is obvious, only a few reports have been published in this topic. Ricinoleic acid was the mostly used monomer, probably based on its availability from castor oil, while other bio-based hydroxy acids can be obtained from unsaturated fatty acids by hydroxylation. To allow a sustainable and efficient process, probably the main effort needs to be directed towards the multi-step process engineering, e.g., the scaling-up of an already patented process of one-pot enzymatic hydrolysis of the oil, hydroxylation of the unsaturated fatty acid, and polymerization [186].

Alongside itaconic acid, hydroxymethyl furfural stand out among the main biobased platform chemicals, being the starting material for several compounds which can be converted to co-polymers by enzymatic processes. Lipases were proved as highly efficient catalysts for such reactions, although other enzymes could be also used, and a real evaluation of the scaling-up possibilities is still to be achieved. 2,5-Furandicarboxylate and 2,5-bis(hydroxymethyl)furan are currently the most important monomers of this class, as demonstrated by the high number of published reports and groups involved in this research topic. It can be expected that new polymers will be synthesized and characterized, the main problem seeming to be the incorporation of an increased number of aromatic rings in the macromolecule's chain when polymers with higher molecular weights are targeted. Undoubtedly, the future looks bright for these co-polymers.

The scientific and industrial interest for polyesteramides is obvious, due to the variety of possible compositions influencing the morphology and mechanical properties of the polymers, biodegradation being another key issue [187]. Despite the rather small number 
of publications up to date, biocatalysis could also contribute to the development of this topic with innovative solutions, mainly based on inclusion of amino acid units in the polymer structure or valorization of the diversity of possible polymer structures derived from $\varepsilon$-caprolactam.

Author Contributions: Conceptualization, A.T., F.P., C.G.B., data curation, A.T., D.M.D., I.C.B., I.B.; writing-original draft preparation, A.T., D.M.D., I.C.B., I.B., F.P. writing-review and editing, A.T., D.M.D., I.C.B., F.P., C.G.B., supervision, F.P., C.G.B.; funding acquisition, F.P., C.G.B. All authors have read and agreed to the published version of the manuscript.

Funding: This work was partially supported by a grant of the Romanian Ministry of Education and Research, CCCDI-UEFISCDI, project number PN-III-P2-2.1-PED-2019-2638, within PNCDI III, contract number 272PED/2020 and partially supported by a grant of the Romanian Ministry of Education and Research, CCCDI-UEFISCDI, project number PN-III-P4-ID-PCE-2020-2177, within PNCDI III, contract number PCE 157/2021.

Institutional Review Board Statement: Not applicable.

Informed Consent Statement: Not applicable.

Data Availability Statement: Not applicable.

Conflicts of Interest: The authors declare no conflict of interest.

\section{References}

1. Brämer, C.O.; Steinbüchel, A. Occurrence, functions and biosynthesis of non-carbohydrate biopolymers. In Renewable Bioresources: Scope and Modification for Non-Food Applications; Stevens, C.V., Verhé, R., Eds.; John Wiley \& Sons Ltd.: Chichester, UK, 2004; pp. 189-207.

2. Bastiaens, L.; Soetemans, L.; D'Hondt, E.; Elst, K. Sources of chitin and chitosan and their isolation. In Chitin and Chitosan: Properties and Applications; Van den Broek, L.A.M., Boeriu, C.G., Eds.; John Wiley \& Sons Ltd.: Weinheim, Germany, 2019; pp. 1-34.

3. MacGregor, E.A. Biopolymers. In Encyclopedia of Physical Science and Technology, 3rd ed.; Meyers, R.A., Ed.; Elsevier: Amsterdam, The Netherlands, 2003; pp. 207-245.

4. Hearle, J.W.S. Fiber production. In UNESCO-Encyclopedia Life Support Systems (EOLSS), 7. Physical Sciences, Engineering and Technology Resources, Materials Science and Engineering; Rawlings, R.D., Ed.; UNESCO: Paris, France, 2019; Volume 2, Available online: https:/ / www.eolss.net/Sample-Chapters/C05/E6-36-03-05.pdf (accessed on 30 March 2021).

5. Miller, S.A. Sustainable polymers: Replacing polymers derived from fossil fuels. Polym. Chem. 2014, 5, 3117-3118. [CrossRef]

6. Hatti-Kaul, R.; Nilsson, L.J.; Zhang, B.; Rehnberg, N.; Lundmark, S. Designing biobased recyclable polymers for plastics. Trends Biotechnol. 2020, 38, 50-67. [CrossRef] [PubMed]

7. Aeschelmann, F.; Carus, M. Bio-based building blocks and polymers in the world: Capacities, production, and applications: Status quo and trends towards 2020. Ind. Biotechnol. 2015, 11, 154-159. [CrossRef]

8. Ahmed, S.T.; Leferink, N.G.H.; Scrutton, N.S. Chemo-enzymatic routes towards the synthesis of bio-based monomers and polymers. Mol. Cat. 2019, 467, 95-110. [CrossRef]

9. Shen., L.; Haufe, J.; Patel, M.K. Product Overview and Market Projection of Emerging Bio-Based Plastics: European Polysaccharide Network of Excellence, Utrecht, The Netherlands. 2009. Available online: https://www.uu.nl/sites/default/files/copernicus_ probip2009_final_june_2009_revised_in_november_09.pdf (accessed on 25 February 2021).

10. Thoen, J.; Busch, R. Industrial chemicals from biomass-Industrial concepts. In Biorefineries-Industrial Processes and Products: Status Quo and Future Directions; Kamm, B., Gruber, P.R., Kamm, M., Eds.; Wiley-VCH Verlag GmbH: Weinheim, Germany, 2005; pp. 347-365.

11. Kawaguchi, H.; Ogino, C.; Kondo, A. Microbial conversion of biomass into bio-based polymers. Bioresour. Technol. 2017, 245, 1664-1673. [CrossRef]

12. Takkellapati, S.; Li, T.; Gonzalez, M.A. An overview of biorefinery-derived platform chemicals from a cellulose and hemicellulose biorefinery. Clean Technol. Environ. Policy 2018, 20, 1615-1630. [CrossRef]

13. Gregory, G.L.; Lopez-Vidal, E.M.; Buchard, A. Polymers from sugars: Cyclic monomer synthesis, ring-opening polymerisation, material properties and applications. Chem. Commun. 2017, 53, 2198-2217. [CrossRef]

14. Straathof, A.J.J.; Bampouli, A. Potential of commodity chemicals to become bio-based according to maximum yields and petrochemical prices. Biofuels Bioprod. Bioref. 2017, 11, 798-810. [CrossRef]

15. Abdelraheem, E.M.M.; Busch, H.; Hanefeld, U.; Tonin, F. Biocatalysis explained: From pharmaceutical to bulk chemical production. React. Chem. Eng. 2019, 4, 1878-1894. [CrossRef]

16. Liu, Y.; Song, L.; Feng, N.; Jiang, W.; Jin, Y.; Li, X. Recent advances in the synthesis of biodegradable polyesters by sustainable polymerization: Lipase-catalyzed polymerization. RSC Adv. 2020, 10, 36230-36240. [CrossRef] 
17. Swainson, S.M.E.; Styliari, I.D.; Taresco, V.; Garnett, M.C. Poly (glycerol adipate) (PGA), an enzymatically synthesized functionalizable polyester and versatile drug delivery carrier: A literature update. Polymers 2019, 11, 1561. [CrossRef]

18. Urbánek, T.; Jäger, E.; Jäger, A.; Hrubý, M. Selectively biodegradable polyesters: Nature-inspired construction materials for future biomedical applications. Polymers 2019, 11, 1061. [CrossRef]

19. Ludwicka, K.; Jedrzejczak-Krzepkowska, M.; Kubiak, K.; Kolodziejczyk, M.; Pankiewicz, T.; Bielecki, S. Medical and cosmetic applications of bacterial nanocellulose. In Bacterial Nanocellulose: From Biotechnology to Bio-Economy; Gama, M., Dourado, F., Bielecki, S., Eds.; Elsevier: Amsterdam, The Netherlands, 2017; pp. 145-165.

20. Cinelli, P.; Coltelli, M.B.; Signori, F.; Morganti, P.; Lazzeri, A. Cosmetic packaging to save the environment: Future perspectives. Cosmetics 2019, 6, 26. [CrossRef]

21. Tripathi, P.; Sinha, S. Industrial biocatalysis: An insight into trends and future directions. Curr. Sustain. Renew. Energy Rep. 2020, 7, 66-72. [CrossRef]

22. Marion, P.; Bernela, B.; Piccirilli, A.; Estrine, B.; Patouillard, N.; Guilbot, J.; Jérôme, F. Sustainable chemistry: How to produce better and more from less? Green Chem. 2017, 19, 4973-4989. [CrossRef]

23. Pellis, A.; Cantone, S.; Ebert, C.; Gardossi, L. Evolving biocatalysis to meet bioeconomy challenges and opportunities. New Biotechnol. 2018, 40, 154-169. [CrossRef]

24. Kobayashi, S.; Uyama, H.; Kimura, S. Enzymatic polymerization. Chem. Rev. 2001, 101, 3793-3818. [CrossRef]

25. Kobayashi, S. Lipase-catalyzed polyester synthesis-A green polymer chemistry. Proc. Jpn. Acad. Ser. B Phys. Biol. Sci. 2010, 86, 338-365. [CrossRef]

26. Kobayashi, S. Enzymatic polymerization. In Polymer Science: A Comprehensive Reference; Matyjaszewski, K., Möller, M., Eds.; Elsevier: Amsterdam, The Netherlands, 2012; Volume 5, pp. 217-237.

27. Kobayashi, S. Enzymatic ring-opening polymerization and polycondensation for the green synthesis of polyesters. Polym. Adv. Technol. 2015, 26, 677-686. [CrossRef]

28. Kobayashi, S. Green polymer chemistry: New methods of polymer synthesis using renewable starting materials. Struct. Chem. 2017, 28, 461-474. [CrossRef]

29. Kobayashi, S.; Uyama, H. Synthesis of polyesters I: Hydrolase as catalyst for polycondensation (condensation polymerization). In Enzymatic Polymerization Towards Green Polymer Chemistry: Green Chemistry and Sustainable Technology; Kobayashi, S., Uyama, H., Kadokawa, J., Eds.; Springer: Singapore, 2019; pp. 105-163.

30. Uyama, H.; Kobayashi, S. Synthesis of polyesters II: Hydrolase as catalyst for ring-opening polymerization. In Enzymatic Polymerization Towards Green Polymer Chemistry: Green Chemistry and Sustainable Technology; Kobayashi, S., Uyama, H., Kadokawa, J., Eds.; Springer: Singapore, 2019; pp. 165-197.

31. Cheng, H.N.; Gross, R.A. Green polymer chemistry: Biocatalysis and biomaterials. In ACS Symposium Series; Cheng, H.N., Gross, R.A., Eds.; American Chemical Society: Washington, DC, USA, 2010; Volume 1043, pp. 1-14.

32. Jiang, Y.; Loos, K. Enzymatic synthesis of biobased polyesters and polyamides. Polymers 2016, 8, 243. [CrossRef] [PubMed]

33. Pellis, A.; Acero, E.H.; Ferrario, V.; Ribitsch, D.; Guebitz, G.M.; Gardossi, L. The closure of the cycle: Enzymatic synthesis and functionalization of bio-based polyesters. Trends Biotechnol. 2016, 34, 316-328. [CrossRef]

34. Lu, Y.; Lv, Q.; Liu, B.; Liu, J. Immobilized Candida antarctica lipase B catalyzed synthesis of biodegradable polymers for biomedical applications. Biomater. Sci. 2019, 7, 4963-4983. [CrossRef]

35. Pellis, A.; Silvestrini, L.; Scaini, D.; Coburn, J.M.; Gardossi, L.; Kaplan, D.L.; Acero, E.H.; Guebitz, G.M. Enzyme-catalyzed functionalization of poly(L-lactic acid) for drug delivery applications. Process Biochem. 2017, 59, 77-83. [CrossRef]

36. Chakraborty, S.; Pagaduan, J.N.M.; Melgar, Z.K.A.; Seitz, S.; Kan, K.; Ajiro, H. Glycerol-modified poly( $\varepsilon$-caprolactone): An biocatalytic approach to improve the hydrophilicity of poly( $\varepsilon$-caprolactone). Polym. Bull. 2019, 76, 1915-1928. [CrossRef]

37. Kántor, I.; Aparaschivei, D.; Todea, A.; Biró, E.; Babos, G.; Szerényi, D.; Kakasi, B.; Péter, F.; Șișu, E.; Feczkó, T. Biocatalytic synthesis of poly[E-caprolactone-co-(12-hydroxystearate)] copolymer for sorafenib nanoformulation useful in drug delivery. Cat. Today 2021, 366, 195-201. [CrossRef]

38. Vilela, C.; Sousa, A.F.; Fonseca, A.C.; Serra, A.C.; Coelho, J.F.J.; Freirea, C.S.R.; Silvestrea, A.J.D. The quest for sustainable polyesters-Insights into the future. Polym. Chem. 2014, 5, 3119-3141. [CrossRef]

39. Taresco, V.; Creasey, R.G.; Kennon, J.; Mantovani, G.; Alexander, C.; Burley, J.C.; Garnett, M.C. Variation in structure and properties of poly(glycerol adipate) viacontrol of chain branching during enzymatic synthesis. Polymer 2016, 89, 41-49. [CrossRef]

40. Martínez de Ilarduya, A.; Muñoz Guerra, S. Ring opening polymerization of macrocyclic oligoesters derived from renewable resources. Polym. Chem. 2020, 11, 4850-4860. [CrossRef]

41. Varma, I.K.; Albertsson, A.C.; Rajkhowa, R.; Srivastava, R.K. Enzyme catalyzed synthesis of polyesters. Prog. Polym. Sci. 2005, 30, 949-981. [CrossRef]

42. Douka, A.; Vouyiouka, S.; Papaspyridi, L.M.; Papaspyrides, C.D. A review on enzymatic polymerization to produce polycondensation polymers: The case of aliphatic polyesters, polyamides and polyesteramides. Prog. Polym. Sci. 2018, 79, 1-25. [CrossRef]

43. Williams, C.K. Synthesis of functionalized biodegradable polyesters. Chem. Soc. Rev. 2007, 36, 1573-1580. [CrossRef] [PubMed]

44. Webb, A.R.; Yang, J.; Ameer, G.A. Biodegradable polyester elastomers in tissue engineering. Expert Opin. Biol. Ther. 2004, 4 , 801-812. [CrossRef] [PubMed]

45. Middleton, J.C.; Tipton, A.J. Synthetic biodegradable polymers as orthopedic devices. Biomaterials 2000, 21, 2335-2346. [CrossRef] 
46. Boland, E.D.; Coleman, B.D.; Barnes, C.P.; Simpson, D.G.; Wnek, G.E.; Bowlin, G.L. Electrospinning polydioxanone for biomedical applications. Acta Biomater. 2005, 1, 115-123. [CrossRef]

47. Gan, Z.; Abe, H.; Doi, Y. Biodegradable poly(ethylene succinate) (PES): 1. Crystal growth kinetics and morphology. Biomacromolecules 2000, 1, 704-712. [CrossRef]

48. Natarajan, J.; Movva, S.; Madras, G.; Chatterjee, K. Biodegradable galactitol based crosslinked polyesters for controlled release and bone tissue engineering. Mater. Sci. Eng. C 2017, 77, 534-547. [CrossRef]

49. Fan, X.; Zhao, Y.; Xu, W.; Li, L. Linear-dendritic block copolymer for drug and gene delivery. Mater. Sci. Eng. C 2016, 62, 943-959. [CrossRef]

50. Wong, P.T.; Choi, S.K. Mechanisms of drug release in nanotherapeutic delivery systems. Chem. Rev. 2015, 115, 3388-3432. [CrossRef]

51. Armentano, I.; Dottori, M.; Fortunati, E.; Mattioli, S.; Kenny, J.M. Biodegradable polymer matrix nanocomposites for tissue engineering: A review. Polym. Degrad. Stab. 2010, 95, 2126-2146. [CrossRef]

52. Zhang, X.; Tan, B.H.; Li, Z. Biodegradable polyester shape memory polymers: Recent advances in design, material properties and applications. Mater. Sci. Eng. C 2018, 92, 1061-1074. [CrossRef]

53. Tomkea, P.D.; Zhaoa, X.; Chiplunkara, P.P.; Xua, B.; Wangc, H.; Silvaf, C.; Rathodb, V.K.; Cavaco-Pauloa, A. Lipase-ultrasound assisted synthesis of polyesters. Ultrason. Sonochem. 2017, 38, 496-502. [CrossRef]

54. Matsumura, S. Enzymatic synthesis of polyesters via ring-opening polymerization. Adv. Polym. Sci. 2006, 194, 95-132.

55. Balaji, A.B.; Pakalapati, H.; Khalid, M.; Walvekar, R.; Siddiqui, H. Natural and synthetic biocompatible and biodegradable polymers. In Biodegradable and Biocompatible Polymer Composites: Processing, Properties and Applications; Shimpi, N.G., Ed.; Woodhead Publishing Series in Composites Science and Engineering; Elsevier: Amsterdam, The Netherlands, 2018 ; pp. 3-32.

56. Abasian, P.; Ghanavati, S.; Rahebi, S.; Khorasani, S.N.; Khalili, S. Polymeric nanocarriers in targeted drug delivery systems: A review. Polym. Adv. Technol. 2020, 31, 2939-2954. [CrossRef]

57. Vargason, A.M.; Anselmo, A.C.; Mitragotri, S. The evolution of commercial drug delivery technologies. Nat. Biomed. Eng. 2021. [CrossRef]

58. Gross, R.A.; Ganesh, M.; Lu, W. Enzyme-catalysis breathes new life into polyester condensation polymerizations. Trends Biotechnol. 2010, 28, 435-443. [CrossRef]

59. Namekawa, S.; Uyama, H.; Kobayashi, S. Enzymatic synthesis of polyesters from lactones, dicarboxylic acid divinyl esters, and glycols through combination of ring-opening polymerization and polycondensation. Biomacromolecules 2000, 1, 335-338. [CrossRef]

60. Tsui, A.; Wright, Z.C.; Frank, C.W. Biodegradable polyesters from renewable resources. Annu. Rev. Chem. Biomol. Eng. 2013, 4, 143-170. [CrossRef]

61. Isnard, F.; Mazzeo, M.; Thomas, C.M. Novel polyesters from renewable resources. L'Actualité Chim. 2018, 427-428, 50-53.

62. Xu, Z.H.; Cheng, A.D.; Xing, X.P.; Zong, M.H.; Bai, Y.P.; Li, N. Improved synthesis of 2,5-bis(hydroxymethyl)furan from 5hydroxymethylfurfural using acclimatized whole cells entrapped in calcium alginate. Bioresour. Technol. 2018, 262, 177-183. [CrossRef]

63. Yu, I.K.M.; Tsang, D.C.W. Conversion of biomass to hydroxymethylfurfural: A review of catalytic systems and underlying mechanisms. Bioresour. Technol. 2017, 238, 716-732. [CrossRef]

64. Rebouillat, S.; Pla, F. Recent strategies for the development of biosourced-monomers, oligomers and polymers-based materials: A review with an innovation and a bigger data focus. J. Biomater. Nanobiotechnol. 2016, 7, 167-213. [CrossRef]

65. Harmsen, P.F.H.; Hackmann, M.M.; Bos, H.L. Green building blocks for bio-based plastics. Biofuels Bioprod. Bioref. 2014, 8, 306-324. [CrossRef]

66. Gubitz, G.M.; Paulo, A.C. New substrates for reliable enzymes: Enzymatic modification of polymers. Curr. Opin. Biotechnol. 2003, 14, 577-582. [CrossRef]

67. Tschan, M.J.L.; Brulé, E.; Haquettea, P.; Thomas, C.M. Synthesis of biodegradable polymers from renewable resources. Polym. Chem. 2012, 3, 836. [CrossRef]

68. Caretto, A.; Noè, M.; Selva, M.; Perosa, A. Upgrading of biobased lactones with dialkylcarbonates. ACS Sustain. Chem. Eng. 2014, 2, 2131-2141. [CrossRef]

69. Naira, L.S.; Laurencin, C.T. Biodegradable polymers as biomaterials. Prog. Polym. Sci. 2007, 32, 762-798. [CrossRef]

70. Ding, C.; Li, Z. A review of drug release mechanisms from nanocarrier systems. Mater. Sci. Eng. C 2017, 76, 1440-1453. [CrossRef]

71. Fan, X.; Wang, Z.; Yuan, D.; Sun, Y.; Li, Z.; He, C. Novel linear-dendritic-like amphiphilic copolymers: Synthesis and self-assembly characteristics. Polym. Chem. 2014, 5, 4069-4075. [CrossRef]

72. Fan, X.; Li, Z.; Loh, X.J. Recent development of unimolecular micelles as functional materials and applications. Polym. Chem. 2016, 7, 5898-5919. [CrossRef]

73. Fonseca, A.C.; Gil, M.H.; Simões, P.N. Biodegradable poly(ester amide)s-A remarkable opportunity for the biomedical area: Review on the synthesis, characterization, and applications. Prog. Polym. Sci. 2014, 39, 1291-1311. [CrossRef]

74. Asín, L.; Armelin, E.; Montané, J.; Rodríguez-Galan, A.; Puiggalí, J. Sequential poly(ester amide)s based on glycine, diols, and dicarboxylic acids: Thermal polyesterification versus interfacial polyamidation: Characterization of polymers containing stiff units. J. Polym. Sci. A Polym. Chem. 2001, 39, 4283-4293. [CrossRef] 
75. Rodriguez-Galan, A.; Franco, L.; Puiggali, J. Degradable Poly(ester amide)s for Biomedical Applications. Polymers 2011, 3, 65-99. [CrossRef]

76. Zilinskas, G.J.; Soleimani, A.; Gillies, E.R. Poly(ester amide)-poly(ethylene oxide) graft copolymers: Towards micellar drug delivery vehicles. Int. J. Polym. Sci. 2012, 2012, 564348. [CrossRef]

77. Chisholm, M.H.; Galucci, J.; Krempner, C.; Wiggenhorn, C. Paper Comments on the ring-opening polymerization of morpholine2,5-dione derivatives by various metal catalysts and characterization of the products formed in the reactions involving $\mathrm{R}_{2} \mathrm{SnX}_{2}$, where $\mathrm{X}=\mathrm{OPr}^{\mathrm{i}}$ and $\mathrm{NMe}_{2}$ and $\mathrm{R}=\mathrm{Bu}^{\mathrm{n}}$, $\mathrm{Ph}$ and $p-\mathrm{Me}_{2} \mathrm{NC}_{6} \mathrm{H}_{4}$. Dalton Trans. 2006, 6, 846-851. [CrossRef] [PubMed]

78. Lu, D.D.; Yuan, J.C.; Lei, Z.Q. High molecular weight biodegraded poly(lactic acid-glycolic acid- $\varepsilon$-caprolactam) copolymer: Direct polycondensation of lactic acid, glycolic acid and $\varepsilon$-caprolactam using Sn(II)-organic anhydride as catalysts. Polym. Adv. Technol. 2009, 20, 536-540. [CrossRef]

79. Nguyen, T.H.N.; Balligand, F.; Bormann, A.; Bennevault, V.; Guégan, P. Synthesis of new biobased linear poly(ester amide)s. Eur. Polym. J. 2019, 121, 109314. [CrossRef]

80. Stavila, E.; Loos, K. Synthesis of polyamides and their copolymers via enzymatic polymerization. J. Renew. Mater. 2015, 3, 268-280. [CrossRef]

81. Winnacker, M.; Rieger, B. Poly(ester amide)s: Recent insights into synthesis, stability, and biomedical applications. Polym. Chem. 2016, 7, 7039-7046. [CrossRef]

82. Kim, B.H.; Lee, C.W.; Gong, M.S. Preparation of polyesteramides based on aliphatic amine-containing phenol derivatives via interfacial polymerization. Macromol. Res. 2003, 11, 328-333. [CrossRef]

83. Jin, S.; Mungara, P.M.; Gonsalves, K.E. Synthesis of polyamides and polyureas containing leucine-tyrosine linkages. J. Polym. Sci. A Polym. Chem. 1997, 35, 499-507. [CrossRef]

84. Lammens, T.M.; Franssen, M.C.R.; Scott, E.L.; Sanders, J.P.M. Availability of protein-derived amino acids as feedstock for the production of bio-based chemicals. Biomass Bioenergy 2012, 44, 168-181. [CrossRef]

85. Yan, N.; Wang, Y. Catalyst: Is the amino acid a new frontier for biorefineries? Chem 2019, 5, 739-743. [CrossRef]

86. Zhou, Y.; Shuke Wu, S.; Li, Z. Cascade biocatalysis for sustainable asymmetric synthesis: From biobased L-phenylalanine to high-value chiral chemicals. Angew. Chem. Int. Ed. 2016, 55, 1-5. [CrossRef]

87. Michell, R.M.; Muller, A.J.; Castelletto, V.; Hamley, I.; Deshayes, G.; Dubois, P. Effect of sequence distribution on the morphology, crystallization, melting, and biodegradation of poly( $\varepsilon$-caprolactone-co- $\varepsilon$-caprolactam) copolymers. Macromolecules 2009, 42 , 6671-6681. [CrossRef]

88. Froidevaux, V.; Negrell, C.; Caillol, S.; Pascault, J.P.; Boutevin, B. Biobased amines: From synthesis to polymers; present and future. Chem. Rev. 2016, 116, 14181-14224. [CrossRef]

89. Liu, Z.-H.; Li, Y.; Zhang, C.-J.; Zhang, Y.-Y.; Cao, X.-H.; Zhang, X.-H. Synthesis of high-molecular-weight poly( $\varepsilon$-caprolactone) via heterogeneous zinc-cobalt(III) double metal cyanide complex. Giant 2020, 3, 100030. [CrossRef]

90. Poojari, Y.; Beemat, J.S.; Clarson, S.J. Enzymatic synthesis of poly( $\varepsilon$-caprolactone): Thermal properties, recovery, and reuse of lipase B from Candida antarctica immobilized on macroporous acrylic resin particles. Polym. Bull. 2013, 70, 1543-1552. [CrossRef]

91. Düşkünkorur, H.Ö.; Pollet, E.; Phalip, V.; Güvenilir, Y.; Avérous, L. Lipase catalyzed synthesis of polycaprolactone and clay-based nanohybrids. Polymer 2014, 55, 1648-1655. [CrossRef]

92. Zhao, H.; Toe, C. "Water-like" ammonium-based ionic liquids for lipase activation and enzymatic polymerization. Process Biochem. 2020, 98, 59-64. [CrossRef]

93. Sandoval, G.; Rivera, I.; Barrera-Rivera, K.A.; Martínez-Richa, A. Biopolymer synthesis catalyzed by tailored lipases. Macromol. Symp. 2010, 289, 135-139. [CrossRef]

94. Zhang, Z.; He, F.; Zhuo, R. Immobilized lipase on porous silica particles: Preparation and application for biodegradable polymer syntheses in ionic liquid at higher temperature. J. Mol. Catal. B Enzym. 2013, 94, 129-135. [CrossRef]

95. Li, G.; Li, Q. Thermophilic esterase from the archaeon Archaeoglobus fulgidus physically immobilized on hydrophobic macroporous resin: A novel biocatalyst for polyester synthesis. Biotechnol. Bioproc. Eng. 2011, 16, 1201-1207. [CrossRef]

96. Barrera-Rivera, K.A.; Marcos-Fernández, Á.; Vera-Graziano, R.; Martínez-Richa, A. Enzymatic ring-opening polymerization of $\varepsilon$-caprolactone by Yarrowia lipolytica lipase in ionic liquids. J. Polym. Sci. A Polym. Chem. 2009, 47, 5792-5805. [CrossRef]

97. Hou, J.; Guo, S. Lipase-catalyzed synthesis and properties of thiol end-functionalized polycaprolactone and poly(ethylene glycol)-b-polycaprolactone. Acta Polym. Sin. 2009, 9, 796-802. [CrossRef]

98. Hans, M.; Gasteier, P.; Keul, H.; Moeller, M. Ring-opening polymerization of $\varepsilon$-caprolactone by means of mono- and multifunctional initiators: Comparison of chemical and enzymatic catalysis. Macromolecules 2006, 39, 3184-3193. [CrossRef]

99. Hedfors, C.; Östmark, E.; Malmström, E.; Hult, K.; Martinelle, M. Thiol end-functionalization of poly( $(\varepsilon$-caprolactone), catalyzed by Candida antarctica lipase B. Macromolecules 2005, 38, 647-649. [CrossRef]

100. Wang, C.; Xiao, Y.; Heise, A.; Lang, M. Organometallic and enzymatic catalysis for ring opening copolymerization of $\varepsilon-$ caprolactone and 4-methyl-e-caprolactone. J. Polym. Sci. A Polym. Chem. 2011, 49, 5293-5300. [CrossRef]

101. Kumar, A.; Kalra, B.; Dekhterman, A.; Gross, R.A. Efficient ring-opening polymerization and copolymerization of $\varepsilon$-caprolactone and $\omega$-pentadecalactone catalyzed by Candida antarctica lipase B. Macromolecules 2000, 33, 6303-6309. [CrossRef]

102. Dreavă, D.M.; Benea, I.C.; Bîtcan, I.; Todea, A.; Sișu, E.; Puiu, M.; Peter, F. Biocatalytic approach for novel functional oligoesters of caprolactone and malic acid. Processes 2021, 9, 232. [CrossRef] 
103. Todea, A.; Bîtcan, I.; Aparaschivei, D.; Păușescu, I.; Badea, V.; Péter, F.; Gherman, V.D.; Rusu, G.; Nagy, L.; Kéki, S. Biodegradable oligoesters of $\varepsilon$-caprolactone and 5-hydroxymethyl-2-furancarboxylic acid synthesized by immobilized lipases. Polymers 2019, 11, 1402. [CrossRef]

104. Barrera-Rivera, K.A.; Martínez-Richa, A. Syntheses and characterization of aliphatic polyesters via Yarrowia lipolytica lipase biocatalysis. In Green Polymer Chemistry: Biocatalysis and Materials II; Cheng, H.N., Gross, R.A., Smith, P.B., Eds.; American Chemical Society: Washington, DC, USA, 2015; Volume 1144, pp. 59-68.

105. Todea, A.; Aparaschivei, D.; Bîtcan, I.; Ledeți, I.V.; Bandur, G.; Péter, F.; Nagy, L.; Kéki, S.; Biró, E. Thermal behavior of oligo[( $\varepsilon-$ caprolactone)-co- $\delta$-gluconolactone] enzymatically synthesized in reaction conditions optimized by experimental design. J. Therm. Anal. Calorim. 2020, 141, 1017-1026. [CrossRef]

106. Todea, A.; Aparaschivei, D.; Badea, V.; Boeriu, C.G.; Peter, P. Biocatalytic route for the synthesis of oligoesters of hydroxy-fatty acids and $\varepsilon$-caprolactone. Biotechnol. J. 2018, 13, 1700629. [CrossRef]

107. Aparaschivei, D.; Todea, A.; Păuşescu, I.; Badea, V.; Medeleanu, M.; Şişu, E.; Puiu, M.; Chiriţă-Emandi, A.; Francisc Peter, F. Synthesis, characterization and enzymatic degradation of copolymers of $\varepsilon$-caprolactone and hydroxy-fatty acids. Pure Appl. Chem. 2016, 88, 1191-1201. [CrossRef]

108. Todea, A.; Biro, E.; Badea, V.; Paul, C.; Cimporescu, A.; Nagy, L.; Kéki, K.; Bandur, G.; Boeriu, C.; Péter, F. Optimization of enzymatic ring-opening copolymerizations involving $\delta$-gluconolactone as monomer by experimental design. Catal. Today 2014, 86, 1781-1792. [CrossRef]

109. Sobczak, M. Enzyme-catalyzed ring-opening polymerization of cyclic esters in the presence of poly(ethylene glycol). J. Appl. Polym. Sci. 2012, 125, 3602-3609. [CrossRef]

110. Woodruff, M.A.; Hutmacher, D.W. The return of a forgotten polymer-Polycaprolactone in the 21st century. Prog. Polym. Sci. 2010, 35, 1217-1256. [CrossRef]

111. Robert, T.; Friebel, S. Itaconic acid-A versatile building block for renewable polyesters with enhanced functionality. Green Chem. 2016, 18, 2922-2934. [CrossRef]

112. Klement, T.; Büchs, J. Itaconic acid-A biotechnological process in change. Bioresour. Technol. 2013, 135, 422-431. [CrossRef]

113. Kane, J.H.; Finlay, A.C.; Amann, P.F. Production of Itaconic Acid, Chas. Pfizer \& Co. U.S. Patent 2385283A, 18 September 1945.

114. Kuenz, A.; Gallenmüller, Y.; Willke, T.; Vorlop, K.D. Microbial production of itaconic acid: Developing a stable platform for high product concentrations. Appl. Microbiol. Biotechnol. 2012, 96, 1209-1216. [CrossRef]

115. Guevarra, E.D.; Tabuchi, T. Accumulation of itaconic, 2-hydroxyparaconic, itatartaric, and malic acids by strains of the genus Ustilago. Agric. Biol. Chem. 1990, 54, 2353-2358. [CrossRef]

116. Tabuchi, T.; Sugisawa, T.; Ishidori, T.; Nakahara, T.; Sugiyama, J. Itaconic acid fermentation by a yeast belonging to the genus Candida. Agric. Biol. Chem. 1981, 45, 475-479. [CrossRef]

117. Levinson, W.E.; Kurtzman, C.P.; Kuo, T.M. Production of itaconic acid by Pseudozyma antarctica NRRL Y-7808 under nitrogenlimited growth conditions. Enzym. Microb. Technol. 2006, 39, 824-827. [CrossRef]

118. Strelko, C.L.; Lu, W.; Dufort, F.J.; Seyfried, T.N.; Chiles, T.C.; Rabinowitz, J.D.; Roberts, M.F. Itaconic acid is a mammalian metabolite induced during macrophage activation. J. Am. Chem. Soc. 2011, 133, 16386-16389. [CrossRef]

119. Pourjavadi, A.; Tehrani, Z.M. Mesoporous silica nanoparticles with bilayer coating of poly(acrylic acid-co-itaconic acid) and human serum albumin (HSA): A pH-sensitive carrier for gemcitabine delivery. Mater. Sci. Eng. C 2016, 61, 782-790. [CrossRef]

120. Milašinović, N.; Knežević-Jugović, Z.; Milosavljević, N.; Filipović, J.; Kalagasidis Krušić, M. Controlled release of lipase from Candida rugosa loaded into hydrogels of N-isopropylacrylamide and itaconic acid. Int. J. Pharm. 2012, 436, 332-340. [CrossRef]

121. Gonçalves, F.A.M.M.; Fonseca, A.C.; Domingos, M.; Gloria, A.; Serra, A.C.; Coelho, J.F.J. The potential of unsaturated polyesters in biomedicine and tissue engineering: Synthesis, structure-properties relationships and additive manufacturing. Prog. Polym. Sci. 2017, 68, 1-34. [CrossRef]

122. El-Hamshary, H. Synthesis and water sorption studies of $\mathrm{pH}$ sensitive poly(acrylamide-co-itaconic acid) hydrogels. Eur. Polym. J. 2007, 43, 4830-4838. [CrossRef]

123. Barrett, D.G.; Merkel, T.J.; Luft, J.C.; Yousaf, M.N. One-step syntheses of photocurable polyesters based on a renewable resource. Macromolecules 2010, 43, 9660-9667. [CrossRef]

124. Guo, B.; Chen, Y.; Lei, Y.; Zhang, L.; Zhou, W.Y.; Rabie, A.B.M.; Zhao, J. Biobased poly(propylene sebacate) as shape memory polymer with tunable switching temperature for potential biomedical applications. Biomacromolecules 2011, 12, 1312-1321. [CrossRef]

125. Dai, J.; Ma, S.; Liu, X.; Han, L.; Wu, Y.; Dai, X.; Zhu, J. Synthesis of bio-based unsaturated polyester resins and their application in waterborne UV-curable coatings. Prog. Org. Coat. 2015, 78, 49-54. [CrossRef]

126. Guarneri, A.; Cutifani, V.; Cespugli, M.; Pellis, A.; Vassallo, R.; Asaro, F.; Ebert, C.; Gardossi, L. Functionalization of enzymatically synthesized rigid poly(itaconate)s via post-polymerization Aza-Michael addition of primary amines. Adv. Synth. Catal. 2019, 361, 2559-2573.

127. Pellis, A.; Corici, L.; Sinigoi, L.; D'Amelio, N.; Fattor, D.; Ferrario, V.; Ebert, C.; Gardossi, L. Towards feasible and scalable solventfree enzymatic polycondensations: Integrating robust biocatalysts with thin film reactions. Green Chem. 2015, 17, 1756-1766. [CrossRef] 
128. Corici, L.; Pellis, A.; Ferrario, V.; Ebert, C.; Cantone, S.; Gardossi, L. Understanding potentials and restrictions of solvent-free enzymatic polycondensation of itaconic acid: An experimental and computational analysis. Adv. Synth. Catal. 2015, 357, 1763-1774. [CrossRef]

129. Jiang, Y.; Woortman, A.J.J.; Alberda Van Ekenstein, G.O.R.; Loos, K. Enzyme-catalyzed synthesis of unsaturated aliphatic polyesters based on green monomers from renewable resources. Biomolecules 2013, 3, 461-480. [CrossRef]

130. Jiang, Y.; Woortman, A.J.J.; Alberda van Ekenstein, G.O.R.; Loos, K. Environmentally benign synthesis of saturated and unsaturated aliphatic polyesters via enzymatic polymerization of biobased monomers derived from renewable resources. Polym. Chem. 2015, 6, 5451-5463. [CrossRef]

131. Aparaschivei, D.; Todea, A.; Frissen, A.E.; Badea, V.; Rusu, G.; Sisu, E.; Puiu, M.; Boeriu, C.G.; Peter, F. Enzymatic synthesis and characterization of novel terpolymers from renewable sources. Pure Appl. Chem. 2019, 91, 397-408. [CrossRef]

132. Brännström, S.; Finnveden, M.; Johansson, M.; Martinelle, M.; Malmström, E. Itaconate based polyesters: Selectivity and performance of esterification catalysts. Eur. Polym. J. 2018, 103, 370-377. [CrossRef]

133. Naves, A.F.; Fernandes, H.T.C.; Immich, A.P.S.; Catalani, L.H. Enzymatic syntheses of unsaturated polyesters based on isosorbide and isomannide. J. Polym. Sci. A Polym. Chem. 2013, 51, 3881-3891. [CrossRef]

134. Jiang, Y.; Alberda van Ekenstein, G.O.R.; Woortman, A.J.J.; Loos, K. Fully biobased unsaturated aliphatic polyesters from renewable resources: Enzymatic synthesis, characterization, and properties. Macromol. Chem. Phys. 2014, 215, $2185-2197$. [CrossRef]

135. Pellis, A.; Hanson, P.A.; Comerford, J.W.; Clark, J.H.; Farmer, T.J. Enzymatic synthesis of unsaturated polyesters: Functionalization and reversibility of the aza-Michael addition of pendants. Polym. Chem. 2019, 10, 843-851. [CrossRef]

136. Müller, F.; Torger, B.; Allertz, P.J.; Jähnichen, K.; Keßler, S.; Müller, M.; Simon, F.; Salchert, K.; Mäurer, H.; Pospiech, D. Multifunctional crosslinkable itaconic acid copolymers for enzyme immobilization. Eur. Polym. J. 2018, 102, 47-55. [CrossRef]

137. Hoffmann, C.; Stuparu, M.C.; Daugaard, A.; Khan, A. Aza-Michael addition reaction: Post-polymerization modification and preparation of PEI/PEG-based polyester hydrogels from enzymatically synthesized reactive polymers. J. Polym. Sci. Part A Polym. Chem. 2014, 53, 745-749. [CrossRef]

138. Yamaguchi, S.; Tanha, M.; Hult, A.; Okuda, T.; Ohara, H.; Kobayashi, S. Green polymer chemistry: Lipase-catalyzed synthesis of bio-based reactive polyesters employing itaconic anhydride as a renewable monomer. Polym. J. 2014, 46, 2-13. [CrossRef]

139. Isbell, T.A. Chemistry and physical properties of estolides. Grasas y Aceites 2011, 62, 8-20. [CrossRef]

140. Hayes, D.G. The catalytic activity of lipases toward hydroxy fatty acid-A review. J. Am. Oil Chem. Soc. 1996, 73, 543-549. [CrossRef]

141. Cermak, S.C.; Isbell, T.A. Synthesis of estolides from oleic and saturated fatty acids. J. Am. Oil Chem. Soc. 2001, 78, 557-565. [CrossRef]

142. Isbell, T.A.; Edgcomb, M.R.; Lowery, B.A. Physical properties of estolides and their ester derivatives. Ind. Crops Prod. 2001, 13, 11-20. [CrossRef]

143. Yu, Y.; Wu, D.; Liu, C.; Zhao, Z.; Yang, Y.; Li, Q. Lipase/esterase-catalyzed synthesis of aliphatic polyesters via polycondensation: A review. Process Biochem. 2012, 47, 1027-1036. [CrossRef]

144. Bodalo, A.; Bastida, J.; Máximo, M.F.; Montiel, M.C.; Gómez, M.; Murcia, M.D. Production of ricinoleic acid estolide with free and immobilized lipase from Candida rugosa. Biochem. Eng. J. 2008, 39, 450-456. [CrossRef]

145. Horchani, H.; Bouaziz, A.; Gargouri, Y.; Sayari, A. Immobilized Staphylococcus xylosus lipase-catalysed synthesis of ricinoleic acid esters. J. Mol. Catal. B Enzym. 2012, 75, 35-42. [CrossRef]

146. Todea, A.; Otten, L.G.; Frissen, A.E.; Arends, I.W.C.E.; Peter, F.; Boeriu, C.G. Selectivity of lipases for estolides synthesis. Pure Appl. Chem 2015, 87, 51-58. [CrossRef]

147. Gandini, A. Progress of polymers from renewable resources: Furans, vegetable oils, and polysaccharides. Chem. Rev. 2016, 116, 1637-1669. [CrossRef]

148. Pellis, A.; Malinconico, M.; Guarneri, A.; Gardossi, L. Renewable polymers and plastics: Performance beyond the green. New Biotechnol. 2021, 60, 146-158. [CrossRef]

149. Burgess, S.K.; Leisen, J.E.; Kraftschik, B.E.; Mubarak, C.R.; Kriegel, R.M.; Koros, W.J. Chain mobility, thermal, and mechanical properties of poly(ethylene furanoate) compared to poly(ethylene terephthalate). Macromolecules 2014, 47, 1383-1391. [CrossRef]

150. Jiang, M.; Liu, Q.; Zhang, Q.; Ye, C.; Zhou, G. A series of furanaromatic polyesters synthesized via direct esterification method based on renewable resources. J. Appl. Polym. Sci. A Polym. Chem. 2011, 50, 1026-1036. [CrossRef]

151. Papageorgiou, G.Z.; Tsanaktsis, V.; Bikiaris, D.N. Synthesis of poly(ethylene furandicarboxylate) polyester using monomers derived from renewable resources: Thermal behavior comparison with PET and PEN. Phys. Chem. Chem. Phys. 2014, 16, 7946-7958. [CrossRef]

152. Jianhui, Z.; Jiali, C.; Wenchun, X.; Pin-Hsuan, C.; Gazzano, M.; Scandola, M.; Gross, R.A. Poly(butylene 2,5-furandicarboxylate), a biobased alternative to PBT: Synthesis, physical properties, and crystal structure. Macromolecules 2013, 46, 796-804.

153. Papageorgiou, G.Z.; Tsanaktsis, V.; Papageorgiou, D.G.; Exarhopoulos, S.; Papageorgiou, M.; Bikinaris, D.N. Evaluation of polyesters from renewable resources as alternatives to the current fossil-based polymers. Phase transitions of poly(butylene 2,5-furan-dicarboxylate). Polymer 2014, 55, 3846-3858. [CrossRef]

154. Мa, J.; Yu, X.; Xu, J.; Pang, Y. Synthesis and crystallinity of poly(butylene 2,5-furandicarboxylate). Polymer 2012, 53, $4145-4151$. [CrossRef] 
155. Ma, J.; Pang, Y.; Wang, M.; Xu, J.; Ma, H.; Nie, X. The copolymerization reactivity of diols with 2,5-furandicarboxylic acid for furan-based copolyester materials. J. Mater. Chem. 2012, 22, 3457-3461. [CrossRef]

156. Papageorgiou, G.Z.; Papageorgiou, D.G.; Tsanaktsis, V.; Bikiaris, D.N. Synthesis of the bio-based polyester poly(propylene 2,5-furan dicarboxylate). Comparison of thermal behavior and solid state structure with its terephthalate and naphthalate homologues. Polymer 2015, 62, 28-38. [CrossRef]

157. Tsanaktsis, V.; Vouvoudi, E.; Papageorgiou, G.Z.; Papageorgiou, D.G.; Chrysafis, K.; Bikinaris, D. Thermal degradation kinetics and decomposition mechanism of polyesters based on 2,5-furandicarboxylic acid and low molecular weight aliphatic diols. J. Anal. Appl. Pyrolysis 2015, 112, 369-378. [CrossRef]

158. Zhou, W.; Wang, X.; Yang, B.; Xu, Y.; Zhang, W.; Zhang, Y.; Ji, J. Synthesis, physical properties and enzymatic degradation of bio-based poly(butylene adipate-co-butylene furandicarboxylate) copolyesters. Polym. Degrad. Stab. 2013, 98, $2177-2183$. [CrossRef]

159. Gomes, M.; Gandini, A.; Silvestre, A.J.D.; Reis, B. Synthesis and characterization of poly(2,5-furan dicarboxylate)s based on a variety of diols. J. Appl. Polym. Sci. A Polym. Chem. 2011, 49, 3759-3768. [CrossRef]

160. Burgess, S.K.; Karvan, O.; Johnson, J.R.; Kriegel, R.M.; Koros, W.J. Oxygen sorption and transport in amorphous poly(ethylene furanoate). Polymer 2014, 55, 4748-4756. [CrossRef]

161. Burgess, S.K.; Kriegel, R.M.; Koros, W.J. Carbon dioxide sorption and transport in amorphous poly(ethylene furanoate). Macromolecules 2015, 48, 2184-2193. [CrossRef]

162. Burgess, S.K.; Mikkilineni, D.S.; Yu, D.B.; Kim, D.J.; Mubarak, C.R.; Kriegel, R.M.; Koros, W.J. Water sorption in poly(ethylene furanoate) compared to poly (ethylene terephthalate): Part 1: Equilibrium sorption. Polymer 2014, 55, 6861-6869. [CrossRef]

163. Burgess, S.K.; Mikkilineni, D.S.; Yu, D.B.; Kim, D.J.; Mubarak, C.R.; Kriegel, R.M.; Koros, W.J. Water sorption in poly(ethylene furanoate) compared to poly(ethylene terephthalate): Part 2: Kinetic sorption. Polymer 2014, 55, 6870-6882. [CrossRef]

164. Jiang, Y.; Woortman, A.J.J.; Alberda van Ekenstein, G.O.R.; Petrovic, D.M.; Loos, K. Enzymatic synthesis of biobased polyesters using 2,5-bis(hydroxymethyl)furan as the building block. Biomacromolecules 2014, 15, 2482-2493. [CrossRef]

165. Jiang, Y.; Maniar, D.; Woortman, A.J.J. Enzymatic polymerization of furan-2,5-dicarboxylic acid-based furanic-aliphatic polyamides as sustainable alternatives to polyphthalamides. Biomacromolecules 2015, 16, 3674-3685. [CrossRef]

166. Jiang, Y.; Alberda van Ekenstein, G.O.R.; Woortman, A.J.J.; Loos, K. A biocatalytic approach towards sustainable furanic-aliphatic polyesters. Polym. Chem. 2015, 6, 5198-5211. [CrossRef]

167. Cruz-Izquierdo, A.; van den Broek, L.A.M.; Serra, J.L.; Llama, M.J.; Boeriu, C.G. Lipase-catalyzed synthesis of oligoesters of 2,5-furandicarboxylic acid with aliphatic diols. Pure Appl. Chem. 2015, 87, 59-69. [CrossRef]

168. Morales-Huerta, J.C.; Ciulik, C.B.; de Ilarduya, A.M.; Muñoz-Guerra, S. Fully bio-based aromatic-aliphatic copolyesters: poly(butylene furandicarboxylate-co-succinate)s obtained by ring opening polymerization. Polym. Chem. 2017, 8, 748-760. [CrossRef]

169. Maniar, D.; Hohmann, K.F.; Woortman, A.J.J.; van Dijken, J.; Loos, K. Enzymatic polymerization of dimethyl 2,5furandicarboxylate and heteroatom diamines. ACS Omega 2018, 3, 7077-7085. [CrossRef]

170. Maniar, D.; Jiang, Y.; Woortman, A.; van Dijken, J.; Loos, K. Furan-based copolyesters from renewable resources: Enzymatic synthesis and properties. ChemSusChem 2019, 12, 990-999. [CrossRef]

171. Pellis, A.; Comerford, J.W.; Weinberger, S.; Guebitz, G.M.; Clark, J.H.; Farmer, T.J. Enzymatic synthesis of lignin derivable pyridine based polyesters for the substitution of petroleum derived plastics. Nat. Commun. 2019, 10, 1762. [CrossRef]

172. Skoczinski, P.; Espinoza Cangahuala, M.K.; Maniar, D.; Albach, R.W.; Bittner, N.; Loos, K. Biocatalytic synthesis of furan-based oligomer diols with enhanced end-group fidelity. ACS Sustain. Chem. Eng. 2020, 8, 1068-1086. [CrossRef]

173. Thiyagarajan, S.; Vogelzang, W.; Knoop, R.J.I.; Frissen, A.E.; van Haveren, J.; van Es, D.S. Biobased furandicarboxylic acids (FDCAs): Effects of isomeric substitution on polyester synthesis and properties. Green Chem. 2014, 16, 1957-1966. [CrossRef]

174. Tsanaktsis, V.; Papageorgiou, G.Z.; Bikiaris, D.N. A facile method to synthesize high molecular weight biobased polyesters from 2,5-furandicarboxylic acid and long chain diols. J. Polym. Sci. Polym. Chem. 2015, 53, 2617-2632. [CrossRef]

175. Morales-Huerta, J.C.; Martınez de Ilarduya, A.; Muñoz-Guerra, S. Blocky poly( $\varepsilon$-caprolactone-co-butylene 2,5-furandicarboxylate) copolyesters via enzymatic ring opening polymerization. J. Polym. Sci. Part A Polym. Chem. 2018, 56, 290-299. [CrossRef]

176. Sharma, B.; Azim, A.; Azim, H.; Gross, R.A.; Zini, E.; Focarete, M.L.; Scandola, M. Enzymatic synthesis and solid-state properties of aliphatic polyesteramides with polydimethylsiloxane blocks. Macromolecules 2007, 40, 7919-7927. [CrossRef]

177. Palsule, A.S.; Poojari, Y. Enzymatic synthesis of silicone fluorinated aliphatic polyesteramides. Polymer 2010, 51, 6161-6167. [CrossRef]

178. Ragupathy, L.; Ziener, U.; Dyllick-Brenzinger, R.; von Vacano, B.; Landfester, K. Enzyme-catalyzed polymerizations at higher temperatures: Synthetic methods to produce polyamides and new poly(amide-co-ester)s. J. Mol. Catal. B Enzym. 2012, 76, 94-105. [CrossRef]

179. Stavila, E.; Alberda van Ekenstein, G.O.R.; Woortman, A.J.J.; Loos, K. Lipase-catalyzed ring-opening copolymerization of $\varepsilon$-caprolactone and $\beta$-lactam. Biomacromolecules 2014, 15, 234-241. [CrossRef]

180. Duchiron, S.W.; Pollet, E.; Givry, S.; Avérous, L. Enzymatic synthesis of amino acids endcapped polycaprolactone: A green route towards functional polyesters. Molecules 2018, 23, 290. [CrossRef]

181. Liang, Y.; Zhang, Y.; Hu, Y.; Xia, B.; Lin, X.; Wu, Q. Lipase-catalyzed synthesis of chiral poly(ester amide)s with an alternating sequence of hydroxy acid and L/D-aspartate units. Polym. Chem. 2018, 9, 1412-1420. [CrossRef] 
182. Gross, R.A.; Kumar, A.; Kalra, B. Polymer synthesis by in vitro enzyme catalysis. Chem. Rev. 2001, 101, 2097-2124. [CrossRef]

183. Jenkins, A.D.; Kratochvíl, P.; Stepto, R.F.T.; Suter, U.W. Glossary of basic terms in polymer science (IUPAC Recommendations 1996). Pure Appl. Chem. 1996, 68, 2287-2311. [CrossRef]

184. Moore, O.B.; Hanson, P.-A.; Comerford, J.W.; Pellis, A.; Farmer, T.J. Improving the post-polymerization modification of bio-based itaconate unsaturated polyesters: Catalyzing aza-michael additions with reusable iodine on acidic alumina. Front. Chem. 2019, 7 , 501. [CrossRef]

185. Chen, Y.; Biresaw, G.; Cermak, S.C.; Isbell, T.A.; Ngo, H.L.; Chen, L.; Durham, A.L. Fatty acid estolides: A review. J. Am. Oil Chem. Soc. 2020, 97, 231-241. [CrossRef]

186. Boeriu, G.G.; Todea, A.; Arends, I.W.C.E.; Otten, L.G. Production of Fatty Acid Estolides. U.S. Patent 10920252B2, 16 February 2015.

187. Toncheva-Moncheva, N.; Jerome, R.; Mateva, R. Impact of the structure of poly( $\varepsilon$-caprolactam) containing polyesteramides on mechanical properties and biodegradation. Polym. Degrad. Stab. 2016, 123, 170-177. [CrossRef] 